\title{
Recent Weakening of the Interannual Relationship between ENSO Modoki and Boreal Summer Tropical Cyclone Frequency over the Western North Pacific
}

\author{
Jinjie SONG \\ State Key Laboratory of Severe Weather, Chinese Academy of Meteorological Sciences, China \\ Philip J. KLOTZBACH \\ Department of Atmospheric Science, Colorado State University, Colorado, USA \\ and
}

Yihong DUAN

State Key Laboratory of Severe Weather, Chinese Academy of Meteorological Sciences, China

(Manuscript received 2 December 2020, in final form 15 April 2021)

\begin{abstract}
This study shows that the impact of El Niño-Southern Oscillation (ENSO) Modoki on boreal summer tropical cyclone (TC) formation over the western North Pacific (WNP) has experienced decadal changes during the past few decades. The correlation between the ENSO Modoki index and TC frequency over the WNP is weak during 1975-1989, becomes strong and significant during 1990-2004, and becomes weak again during 2005-2019. Over the eastern part of the WNP, ENSO Modoki enhanced TC formation during 1990-2004 but did not significantly impact on the TC formation during 1975-1989 and 2005-2019. The difference in correlation strength primarily results from changes in large-scale features related to ENSO Modoki among the three subperiods (1975-1989, 1990-2004, and 2005-2019). El Niño Modoki during 1990-2004 was characterized by a tripole sea surface temperature (SST) pattern with maximum SST anomalies in the equatorial central Pacific, while during 1975-1989 and 2005-2019, the maximum SST anomalies were located over the subtropical northeastern Pacific. The two primary environmental variables likely leading to these observed relationships between ENSO Modoki and TCs were mid-level moisture (RH600) and low-level vorticity (VOR850). During 1990-2004, TC formation was enhanced both south of $20^{\circ} \mathrm{N}$ and north of $20^{\circ} \mathrm{N}$. The increase in TC activity during El Niño Modoki south of $20^{\circ} \mathrm{N}$ was likely tied to greater RH600 and north of $20^{\circ} \mathrm{N}$ to larger cyclonic VOR850. In contrast, ENSO Modoki's impacts on both VOR850 and RH600 were weak during 1975-1989 and 2005-2019.
\end{abstract}

Keywords tropical cyclone; El Niño-Southern Oscillation Modoki; western North Pacific

Citation Song, J., P. J. Klotzbach, and Y. Duan, 2021: Recent weakening of the interannual relationship between ENSO Modoki and boreal summer tropical cyclone frequency over the western North Pacific. J. Meteor. Soc. Japan, 99, 1071-1088, doi:10.2151/jmsj.2021-051.

Corresponding author: Jinjie Song, 46 Zhongguancun South

Avenue, Beijing 100081, China

E-mail: songjinjie@qq.com

J-stage Advance Published Date: 27 April 2021

(C) The Author(s) 2021. This is an open access article published by the Meteorological Society of Japan under a Creative Commons Attribution 4.0 International (CC BY 4.0) license (https://creativecommons.org/licenses/by/4.0). 


\section{Introduction}

The El Niño-Southern Oscillation (ENSO) phenomenon is the leading mode of global climate variability on timescales ranging from a few months to several years and is characterized by a large-scale oceanic warming/cooling event over the tropical Pacific and a seesaw pattern in sea level pressure between the western and eastern tropical Pacific (Wang et al. 2017). More recently, ENSO has been categorized into two flavors: canonical ENSO (also known as conventional ENSO, eastern Pacific ENSO, or cold tongue ENSO) with maximum oceanic warming/cooling over the eastern equatorial Pacific and ENSO Modoki (also known as central Pacific ENSO or warm pool ENSO) with sea surface temperature (SST) variability centered over the central equatorial Pacific (Kao and $\mathrm{Yu}$ 2009; Capotondi et al. 2015; Timmermann et al. 2018).

ENSO is a dominant factor in modulating interannual variability related to tropical cyclones (TCs) in individual TC basins (Emanuel 2018). The western North Pacific (WNP) is the most TC-active basin on an annually averaged basis, accounting for around one-third of global TCs (Chan 2005; Ma et al. 2020; Huang et al. 2021). WNP TC activity is more effectively influenced by ENSO Modoki than canonical ENSO, especially for the number of basinwide TCs (Chen and Tam 2010; Zhang et al. 2015; Patricola et al. 2018). While canonical ENSO does not have a significant impact on overall WNP TC frequency, it does significantly modulate the average TC formation location (Lander 1994; Chan 1985, 2000; Saunders et al. 2000; Wang and Chan 2002; Li and Zhou 2012). WNP TCs on average form more southward and eastward in canonical El Niño years due to more conducive environmental conditions, including warmer SSTs, greater mid-level relative humidity, and lower vertical wind shear in the southeastern quadrant of the WNP relative to canonical La Niña years (Wang and Chan 2002).

In contrast, Chen and Tam (2010) reported that basinwide WNP TC frequency was significantly positively correlated with the ENSO Modoki index (EMI). WNP TC formation is greatly enhanced in El Niño Modoki years due to a large-scale anomalous cyclonic circulation, anomalous ascending motion, and an anomalously moist mid-troposphere in response to the peak oceanic warming over the central Pacific (Chen and Tam 2010; Kim et al. 2011; Patricola et al. 2018).

The aforementioned close relationship between EMI and WNP TC frequency during the TC-active season is primarily attributed to the correlation be- tween the two indices in boreal summer (hereafter summer), whereas the correlation is weak in boreal autumn (hereafter autumn) (Chen and Tam 2010; Choi et al. 2019). There is also a significant increase in summer WNP TC frequency during El Niño Modoki years, whereas the difference in autumn WNP TC frequency is not significant between climatology and El Niño Modoki years (Choi et al. 2019). During El Niño Modoki years, although there is enhanced TC formation east of $140^{\circ} \mathrm{E}$ in both summer and autumn, the frequency of $\mathrm{TC}$ formation west of $140^{\circ} \mathrm{E}$ does not change significantly in summer but is significantly suppressed in autumn. Mid-level relative humidity was found to be the dominant contributor to the difference in El Niño Modoki modulation of WNP TC formations during summer and autumn (Choi et al. 2019). There is a significant decrease in vertically integrated $(1000-100 \mathrm{hPa})$ moisture flux convergence during El Niño Modoki autumns, inducing a reduction in tropospheric moisture that then suppresses TC formation.

Moreover, Liu and Chen (2018) noted an intensified connection between ENSO Modoki and summer WNP TC formation since the early 1990s, which was mainly caused by interdecadal changes in the spatiotemporal variability of ENSO Modoki. SST variations in response to ENSO Modoki covered a larger portion of the central Pacific in 1991-2011 than in 1950-1990. Since around 1990, El Niño Modoki has tended to result in an intensified and northwestward-expanded anomalous cyclonic circulation over the WNP, whereas La Niña Modoki has tended to induce an anomalous anticyclonic circulation over the WNP, subsequently enhancing the impact of ENSO Modoki on WNP TC formation. Liu and Chen (2018) further linked changes in the characteristics of ENSO Modoki to anthropogenic global warming. They argued that anthropogenic global warming had induced an El Niño Modoki-like warming in the central Pacific and consequently an increasing proportion of ENSO Modoki events to canonical ENSO events.

Recently, Choi et al. (2016) highlighted decadal variations in WNP TC frequency since the mid-1990s and found that the average number of WNP TCs during summer was significantly reduced since the mid-2000s. They attributed this change to a strengthened anomalous anticyclonic circulation across most of the tropical WNP after the mid-2000s, as well as the westward retreat of the monsoon trough and the westward expansion of the West Pacific subtropical high.

This study ties together these previous studies by 
investigating whether the relationship between ENSO Modoki and WNP TC frequency has changed during the past few decades. While several recent papers showed a larger average number of WNP TCs in El Niño Modoki years than in canonical El Niño years, the identified El Niño Modoki years were all before the mid-2000s (Hsu et al. 2013; Patricola et al. 2018). Zhao and Wang (2019) have classified two years as El Niño Modoki since the mid-2000s: 2006 and 2009. Both years had below normal TC activity over the WNP (O'hara and Falvey 2006; Cooper and Falvey 2009). Consequently, we speculate that ENSO Modoki has exerted a weaker influence on WNP TC formation since the mid-2000s.

The objectives of this study are to document decadal changes in the interannual relationship between ENSO Modoki and WNP TC frequency during the summer and to understand the mechanisms responsible for these changes based on statistical analyses. We focus on the period starting from 1975, in order to compare with the decadal variations in ENSO Modoki modulation on WNP TC formation prior to the 1990s which is shown in Liu and Chen (2018).

The remainder of this study is organized as follows. Section 2 describes the data and analysis methods. Section 3 shows differences in WNP TC formations as modulated by ENSO Modoki during three 15-year subperiods from 1975 to 2019, while differences in large-scale environmental variables are discussed in Section 4. A possible explanation for the observed differences is presented in Section 5. The main conclusions are given in Section 6.

\section{Data and methods}

WNP TC best track data for the period of 19452019 are from the Joint Typhoon Warning Center (Chu et al. 2002) as archived in the International Best Track Archive for Climate Stewardship v4 dataset (Knapp et al. 2010). The date of TC formation is defined as the first record in each best track (Ritchie and Holland 1999; Lee et al. 2008; Yoshida and Ishikawa 2013). This study only considers TCs forming over the WNP in the summer (June-August; JJA) that reached at least 34 knots during their lifetimes. Similar to Fudeyasu et al. (2018), TCs that first developed over the eastern North Pacific and subsequently entered the WNP are excluded. The spatial TC formation density is first obtained by counting TC formation numbers over a $5^{\circ} \times 5^{\circ}$ grid and is then smoothed using the method proposed by Kim et al. (2011). Our results are not significantly changed without the smoothing (figure not shown).
Monthly mean SST data are obtained from the National Oceanic and Atmospheric Administration Extended Reconstructed SST v5 (Huang et al. 2017), with a horizontal resolution of $2^{\circ} \times 2^{\circ}$. Monthly mean atmospheric data are provided by the National Centers for Environmental Prediction-National Center for Atmospheric Research reanalysis on a $2.5^{\circ} \times 2.5^{\circ}$ grid (Kalnay et al. 1996). A cubic spline interpolation to a $2^{\circ} \times 2^{\circ}$ grid is applied to these atmospheric fields for computing the maximum potential intensity (MPI; Emanuel 1988) and the genesis potential index (GPI; Emanuel and Nolan 2004). Instead of relative humidity at $700 \mathrm{hPa}$, as originally used in Emanuel and Nolan (2004), mid-level moisture is measured by relative humidity at $600 \mathrm{hPa}$ (RH600) because the GPI, including RH600, can well describe TC formation changes related to ENSO (Camargo et al. 2007). Figure 1 highlights that the spatial distribution of WNP TC formation is similar to the climatological GPI (1975-2019). More TC occurrences and larger GPIs are observed to the east of the Philippines, corresponding to higher MPI, larger RH600, greater 850 -hPa relative vorticity (VOR850) and lower 850$200-\mathrm{hPa}$ vertical wind shear (SHR). All oceanic and atmospheric variables are calculated as seasonal means during JJA. Our results do not significantly change if the influences of TCs on monthly mean fields over TC-active regions are excluded (figures not shown).

The EMI is defined by Ashok et al. (2007) as $\mathrm{EMI}=[\mathrm{SSTA}]_{C}-0.5 \times[\mathrm{SSTA}]_{E}-0.5 \times[\mathrm{SSTA}]_{W}$, where SSTA denotes the SST anomaly from the climatological (1990-2019) mean, and the brackets indicate the areal averages in Regions $\mathrm{C}\left(10^{\circ} \mathrm{S}-10^{\circ} \mathrm{N}\right.$, $\left.165^{\circ} \mathrm{E}-140^{\circ} \mathrm{W}\right), \mathrm{E}\left(15^{\circ} \mathrm{S}-5^{\circ} \mathrm{N}, 110-70^{\circ} \mathrm{W}\right)$, and $\mathrm{W}$ $\left(10^{\circ} \mathrm{S}-20^{\circ} \mathrm{N}, 125-145^{\circ} \mathrm{E}\right)$, respectively. In addition, the SST index component of the Pacific Meridional Mode (PMM) is obtained from the Physical Sciences Laboratory of the National Oceanic and Atmospheric Administration.

The significance levels of correlation coefficients are estimated using a two-tailed Student's $t$-test, while the significance levels of regression coefficients are given by an $F$-test.

\section{ENSO Modoki-WNP TC formation relationship}

Figure $2 \mathrm{a}$ shows a significant (albeit relatively weak) positive relationship between WNP TC frequency and the EMI during the summer for the period of 1945-2019 ( $r=0.26 ; p=0.02)$, consistent with Chen and Tam (2010). However, this relationship 
a) TC Formation

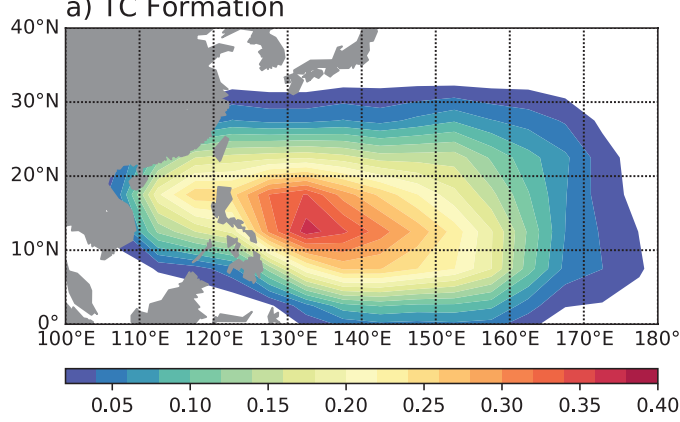

C) Maximum Potential Intensity

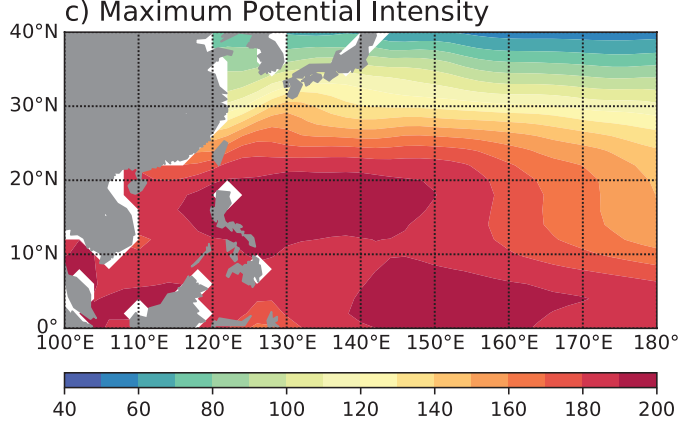

e) 850-hPa Relative Vorticity

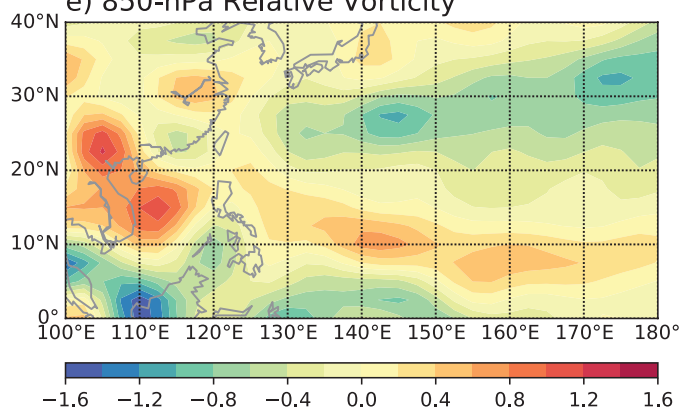

b) Genesis Potential Index

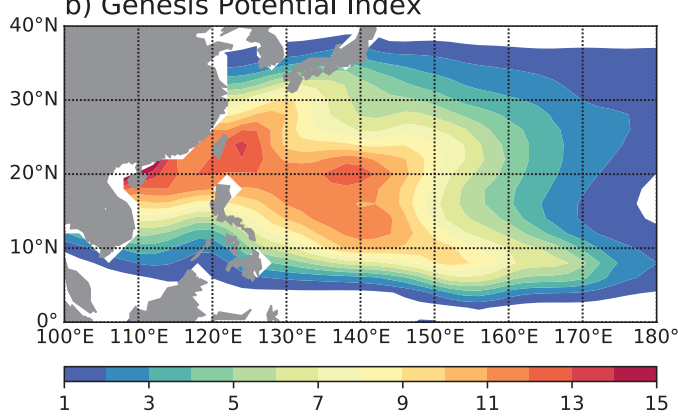

d) 600-hPa Relative Humidity

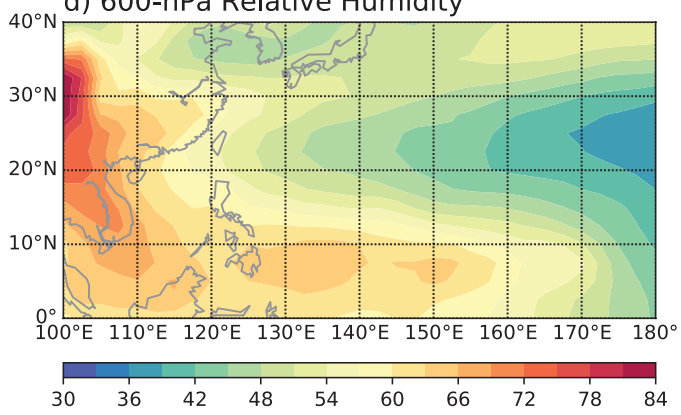

f) $850-200-\mathrm{hPa}$ Vertical Wind Shear

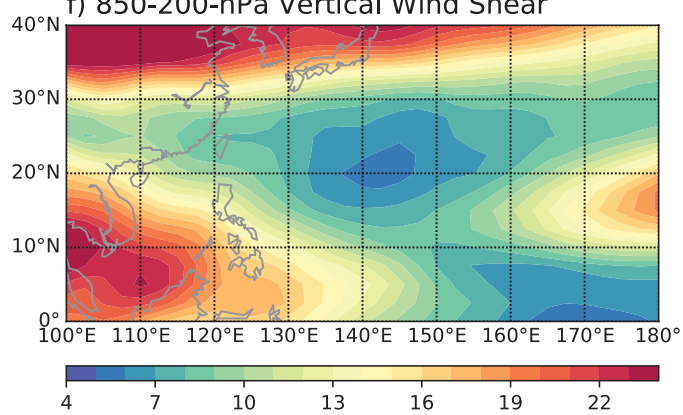

Fig. 1. Climatology (1975-2019) of June-August averaged (a) TC formation density, (b) genesis potential index, (c) maximum potential intensity (knots), (d) 600-hPa relative humidity (\%), (e) $850-\mathrm{hPa}$ relative vorticity $\left(\times 10^{-5} \mathrm{~s}^{-1}\right)$ and (f) 850-200-hPa vertical wind shear $\left(\mathrm{m} \mathrm{s}^{-1}\right)$.

is dominated by the TC frequency-EMI linkage on decadal timescales, while the connection is weaker on shorter timescales (Fig. 2b). Given that the lower quality of TC best track data prior to the 1970s (Chu et al. 2002), we focus on the latter period of 1975-2019 in the analysis that follows. Although WNP TC frequency is significantly correlated with the EMI between 1975 and $2019(r=0.41 ; p<0.01)$, the correlation is not stable during the full 45-yr period (Fig. 2a).

Figure 2c displays running correlations between WNP TC frequency and the EMI in three running windows ranging in width from 11 to 21 years, similar to Gershunov et al. (2001). Three subperiods (19751989, 1990-2004, and 2005-2019) are classified according to changes in the running correlations between WNP TC frequency and EMI. Although running correlations in various windows do not always agree, all correlation windows show an increasing tendency from $\sim 1975$ to early 2000 s and a decreasing tendency after that time. The ENSO Modoki-WNP TC relationship is weak during the first subperiod (1975-1989), becomes strong during the second subperiod (1990-2004), and becomes weak again during the third subperiod (2005-2019).

A strong interannual relationship only occurs during the second subperiod (1990-2004) when WNP TC frequency is significantly correlated with the EMI $(r=0.71 ; p<0.01)$, indicating a strong modulation 

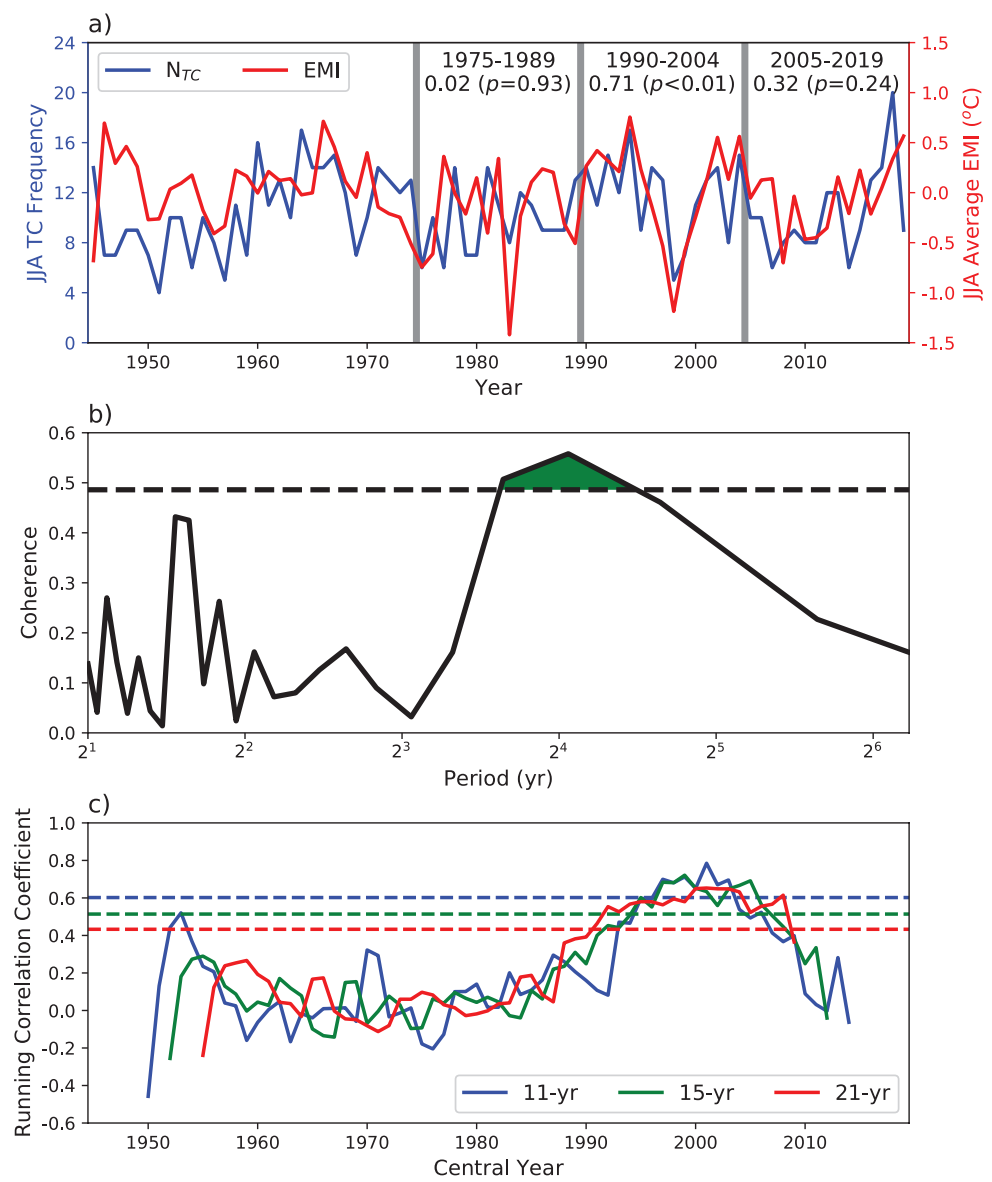

Fig. 2. (a) Annual variation of JJA TC frequency over the WNP (blue solid line) and JJA average EMI (red solid line) during 1945-2019. Correlation coefficients between the two time series and their corresponding significance levels are given in the panel for each of the three 15-yr sub-periods: 1975-1989, 1990-2004 and $2005-2019$. (b) Coherence between JJA WNP TC frequency and JJA average EMI in 1945-2019. The dashed line denotes the 0.05 significance level based on an $F$-test. (c) Running correlation coefficients between JJA WNP TC frequency and JJA mean EMI in sliding windows of 11 (red solid line), 15 (green solid line) and 21 (red solid line) yrs. Horizontal dashed lines represent 0.05 significance levels based on a Student's $t$-test for each respective correlation coefficient.

of WNP TC formation by ENSO Modoki. Nearly all the El Niño Modoki years classified in previous publications (Kim et al. 2011; Hsu et al. 2013; Patricola et al. 2018) occurred during this subperiod. By contrast, ENSO Modoki appears to have had only a minor impact on summertime WNP TC frequency during the first and third subperiods (1975-1989 and 2005-2019), with a weak correlation between WNP TC frequency and the EMI $(r=0.02 ; p=0.93$ and $r=0.32 ; p=0.24$, respectively). These results imply that there is a decadal change in the ENSO ModokiWNP TC relationship during 1975-2019.

Besides the strengthening relationship since the early 1990s, as reported by Liu and Chen (2018), a weakening relationship has been observed in recent years, with a change point in the relationship occurring during the mid-2000s. Note that this change was not mentioned in Liu and Chen (2018). This discrepancy is possibly caused by our study, including several more years of data, and using shorter windows than that of Liu and Chen (2018) to estimate running correlations.

Furthermore, Table 1 highlights the distinct roles of El Niño Modoki and La Niña Modoki on modulating the ENSO Modoki-WNP TC relationship. Since each of these subperiods represent a relatively 
Table 1. TC frequency anomalies and mean anomalies for different ENSO Modoki phases in three 15-yr sub-periods. The TC frequency anomaly is obtained by subtracting the original TC frequency from the 15 -yr average in its corresponding sub-period. During each sub-period, the five years with the highest (lowest) EMI are considered as El Niño Modoki (La Niña Modoki).

\begin{tabular}{|c|c|c|c|c|c|c|}
\hline \multirow{3}{*}{ Period } & \multicolumn{2}{|c|}{ 1975-1989 } & \multicolumn{2}{|c|}{ 1990-2004 } & \multicolumn{2}{|c|}{ 2005-2019 } \\
\hline & El Niño & La Niña & El Niño & La Niña & El Niño & La Niña \\
\hline & Modoki & Modoki & Modoki & Modoki & Modoki & Modoki \\
\hline \multirow{5}{*}{$\begin{array}{l}\text { Year } \\
\text { (TC frequency } \\
\text { anomaly) }\end{array}$} & $1977(-3.7)$ & $1975(-3.7)$ & $1991(-0.9)$ & $1996(2.1)$ & $2007(-4.3)$ & $2008(-2.3)$ \\
\hline & $1980(-2.7)$ & $1976(0.3)$ & $1992(3.1)$ & $1997(-0.1)$ & $2013(1.7)$ & $2010(-2.3)$ \\
\hline & $1982(1.3)$ & $1981(4.3)$ & $1994(5.1)$ & $1998(-6.9)$ & $2015(-1.3)$ & $2011(-2.3)$ \\
\hline & $1986(-0.7)$ & $1983(-1.7)$ & $2002(2.1)$ & $1999(-4.9)$ & 2018 ( 9.7) & $2012(1.7)$ \\
\hline & $1987(-0.7)$ & $1989(3.3)$ & $2004(3.1)$ & $2000(-0.9)$ & $2019(-1.3)$ & $2016(2.7)$ \\
\hline $\begin{array}{l}\text { Mean } \\
\text { (significance level) }\end{array}$ & $\begin{array}{c}-1.3 \\
(p=0.16)\end{array}$ & $\begin{array}{c}0.5 \\
(p=0.76)\end{array}$ & $\begin{array}{c}2.5 \\
(p=0.03)\end{array}$ & $\begin{array}{c}-2.1 \\
(p=0.04)\end{array}$ & $\begin{array}{c}0.9 \\
(p=0.71)\end{array}$ & $\begin{array}{c}-0.5 \\
(p=0.69)\end{array}$ \\
\hline
\end{tabular}

short time span, El Niño Modoki (La Niña Modoki) phases are taken to be the five years with the highest (lowest) EMI during each subperiod, instead of the traditional approach of using the standard deviation of the EMI as a threshold (e.g., Liu and Chen 2018). During the first and third subperiods (1975-1989 and 2005-2019), WNP TC frequency does not show significant alterations between El Niño Modoki and La Niña Modoki years, consistent with the weak TC frequency-EMI correlation shown in Fig. 1a. By comparison, TC formation is significantly increased in El Niño Modoki years and decreased in La Niña Modoki years during 1990-2004, with an average of 2.5 more TC formations in El Niño Modoki and an average of 2.1 fewer TC formations in La Niña Modoki compared with the 15 -year mean. This result implies that the significant TC frequency-EMI relationship in this subperiod is caused by both the enhancing effect of El Niño Modoki and the suppressing effect of La Niña Modoki on WNP TC formation.

Correspondingly, the spatial characteristics of WNP TC formation, as modulated by ENSO Modoki, exhibit changes around the early 1990s and the mid-2000s (Fig. 3). Figures 3a, 3d, and 3g show the regressions of TC formation density on the EMI for these three subperiods. These regressions exhibit similar spatial patterns to the distribution of correlations between TC formation density and EMI (figures not shown). During 1975-1989, TC formation is enhanced over the Philippine Sea and east of $150^{\circ} \mathrm{E}$, whereas it is suppressed over the South China Sea and between $135^{\circ} \mathrm{E}$ and $150^{\circ} \mathrm{E}$ (Fig. 2a). None of these TC formation changes are statistically significant, confirming that ENSO Modoki only has a minor impact on modulating WNP TC formation during this subperiod.
These results are also consistent with the lack of significant changes in TC formation anomalies during El Niño Modoki or La Niña Modoki years during this subperiod (Figs. 3b, c).

During 1990-2004, the EMI-regressed TC formation density shows a tripolar pattern, with suppressed TC formation over the Philippine Sea and enhanced TC formation over the South China Sea and east of $130^{\circ} \mathrm{E}$ (Fig. 3d). This pattern is similar to that found by Liu and Chen (2018) for the period of 1991-2011 and by Choi et al. (2019) for the period of 1979-2016. Furthermore, significantly enhanced TC formation is observed over the region from $0^{\circ}$ to $20^{\circ} \mathrm{N}$ and $130^{\circ} \mathrm{E}$ to $165^{\circ} \mathrm{E}$ (Fig. 3d), which is somewhat of a westward shift in significant TC formation compared with that found by Choi et al. (2019). This difference may be due to different analysis methods and study periods employed in their study. Moreover, TC formation is enhanced (suppressed) over most of the WNP during El Niño Modoki (La Niña Modoki) years of 1990-2004, with significant increases (decreases) concentrated east (west) of $150^{\circ} \mathrm{E}$ (Figs. 3e, f). The distribution of TC formation density anomalies in $\mathrm{La}$ Niña Modoki mirrors that in El Niño Modoki, with a pattern correlation coefficient of $-0.55(p<0.01)$. These two patterns in El Niño Modoki and La Niña Modoki are also similar to the pattern in Fig. $3 \mathrm{~d}(r=$ $0.56 ; p<0.01$ and $r=-0.86 ; p<0.01$, respectively), implying that both El Niño Modoki and La Niña Modoki contribute to the TC frequency-EMI relationship.

During 2005-2019, the regions of enhanced TC formation are concentrated within the latitudinal band of $10-20^{\circ} \mathrm{N}$, with three centers located over the South China Sea, the Philippine Sea, and east of $150^{\circ} \mathrm{E}$ (Fig. 

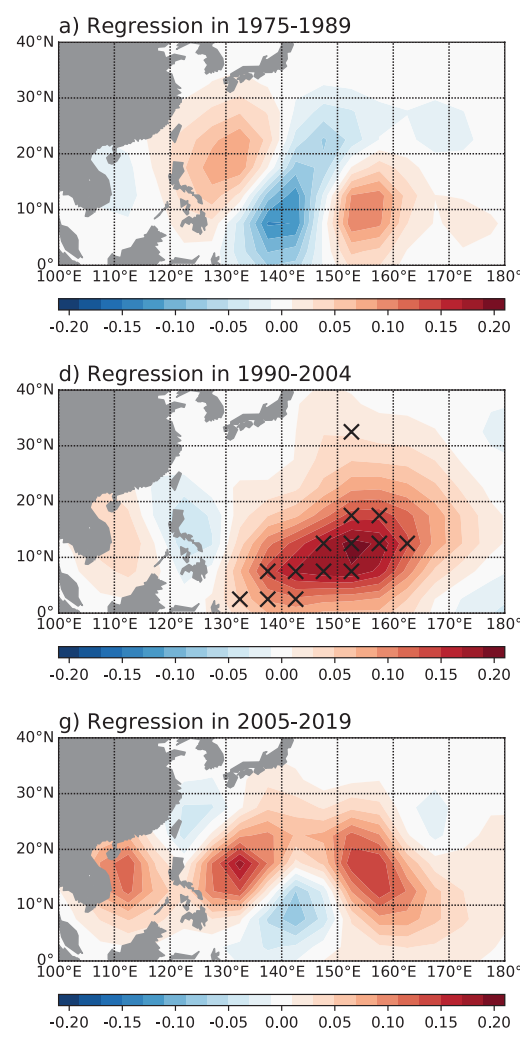
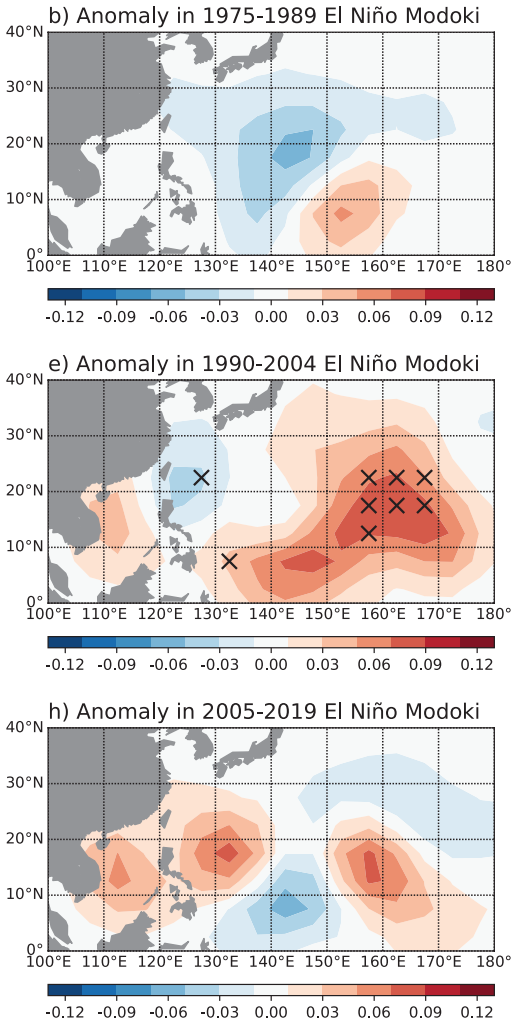
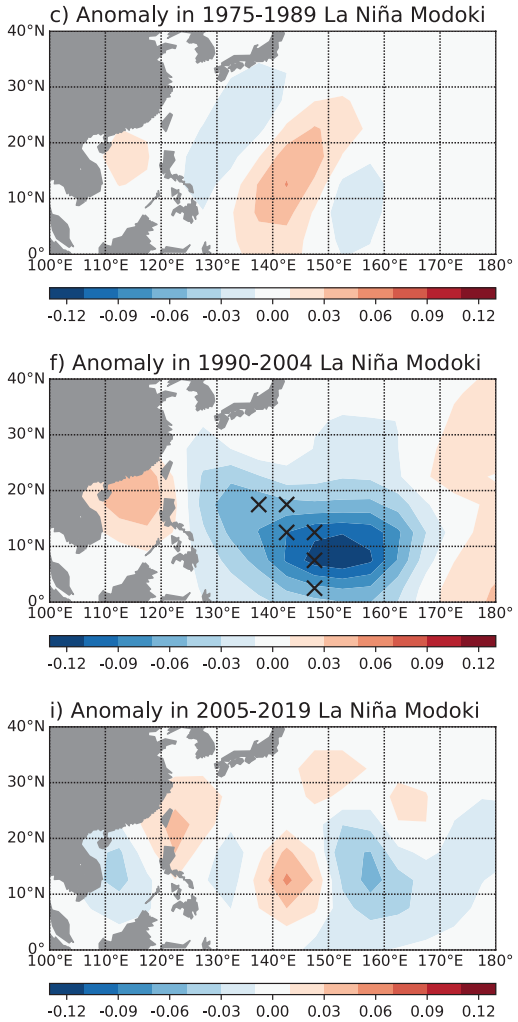

Fig. 3. Regressions of JJA WNP TC formation density on simultaneous EMI (left column) and TC formation anomalies for El Niño Modoki (middle column) and for La Niña Modoki (right column) during (a-c) 1975-1989, (d-f) 1990-2004 and (g-i) 2005-2019. Black crosses denote regressions significant at the 0.05 level based on an $F$-test in $(\mathrm{a}, \mathrm{d}, \mathrm{g})$, while they refer to anomalies significant at the 0.05 level based on a Student's $t$-test in other panels.

$3 \mathrm{~g})$. Suppressed TC formation occurs to the east of Taiwan and over the region bounded by $0-15^{\circ} \mathrm{N}$ and $130-150^{\circ} \mathrm{E}$. As in $1975-1989$, none of the TC formation density anomalies are significantly linked to the EMI in 2005-2019. These findings further confirm a limited role for ENSO Modoki in modulating WNP $\mathrm{TC}$ formation during this subperiod. Although there are different spatial patterns in TC formation changes during the first and third subperiods, there are no significant TC formation density anomalies observed in El Niño Modoki or La Niña Modoki (Figs. 3b, c, h, i).

\section{Large-scale environmental conditions}

Figure 4 displays a regression of the GPI on the EMI during JJA of these three subperiods, as well as GPI anomalies in both El Niño and La Niña Modoki years. Similar patterns can be found in the spatial distribution of correlations between the GPI and EMI (figures not shown). During 1975-1989, there are few significant GPI changes related to the EMI over the WNP, except for in the tropics near the dateline (Fig. 4a). This pattern is remarkably similar to the distribution of GPI anomalies during El Niño Modoki $(r=0.80 ; p<0.01$; Fig. $4 \mathrm{~b})$ and is nearly a mirror image of the GPI anomaly distribution during La Niña Modoki ( $r=-0.72 ; p<0.01$; Fig. $4 \mathrm{c})$.

During 1990-2004, there is a positive regression relationship between the EMI and the GPI over the South China Sea and east of $130^{\circ}$ E (Fig. 4d), which corresponds well with the positive regression relationship between the EMI and TC formation density anomalies (Fig. 3d). GPIs are significantly positively regressed on the EMI east of $130^{\circ} \mathrm{E}$, extending northwestward from the southeastern quadrant of the WNP (Fig. 4d). During this same subperiod, the GPI has a positive regression relationship with the EMI over the Philippine Sea (Fig. 4d), which is inconsistent with the suppressed TC formation shown in Fig. 3d. However, we do note that most of the regression coefficients in this region are insignificant. During 1990-2004, 

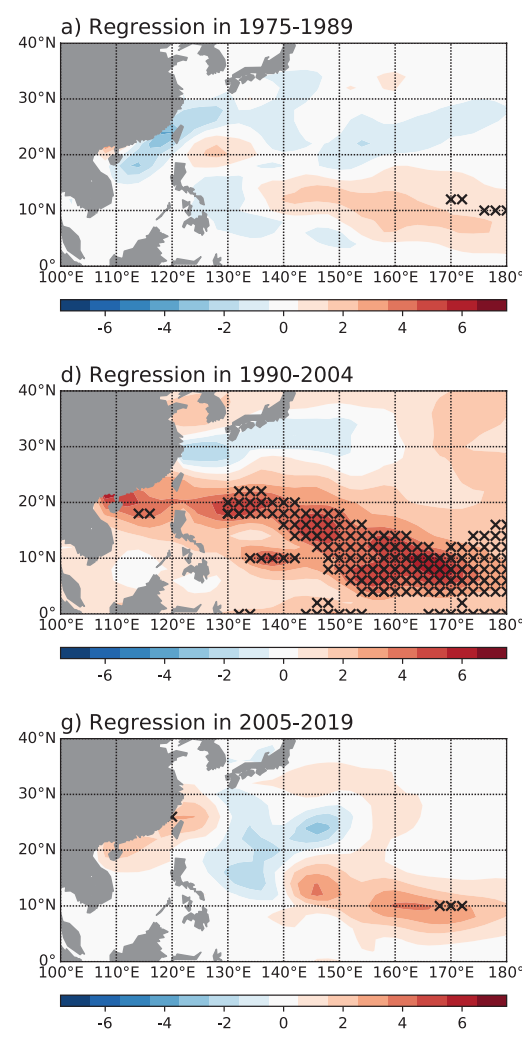
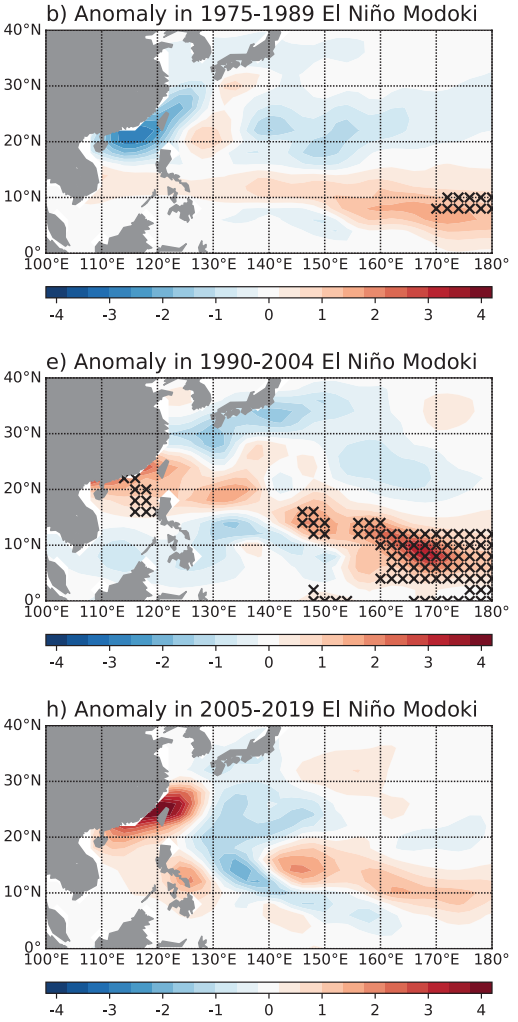
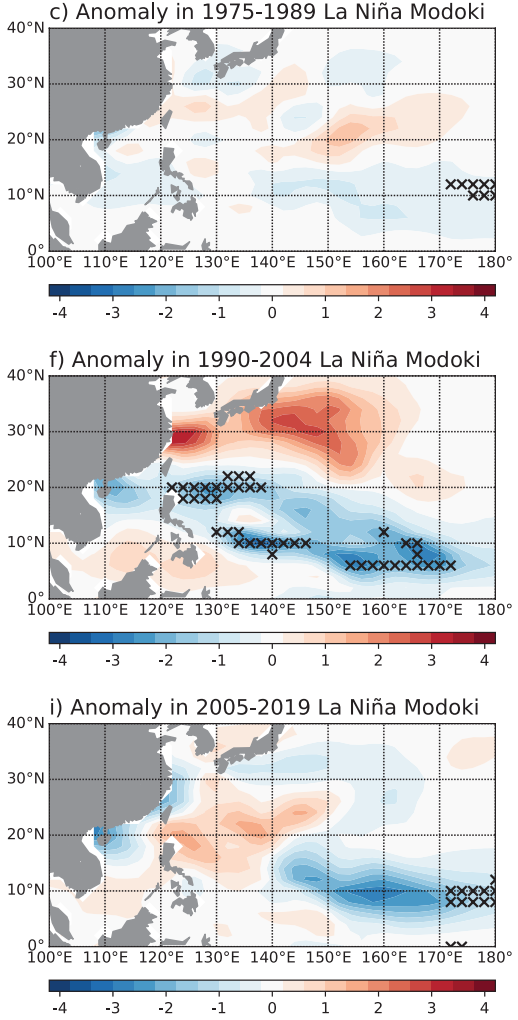

Fig. 4. As in Fig. 3, but for regressions of the GPI on the EMI and GPI anomalies for El Niño Modoki and for La Niña Modoki.

the pattern of GPI anomalies for El Niño Modoki is similar to the pattern of regressed GPI on the EMI $(r=0.72 ; p<0.01$; Fig. $4 \mathrm{e})$ and is nearly the opposite pattern for La Niña Modoki $(r=-0.92 ; p<0.01$; Fig. 4f).

By contrast, during 2005-2019, very little of the WNP has a significant regression of the GPI on the EMI (Fig. 4g) or has significant GPI anomalies in either El Niño Modoki or La Niña Modoki years (Figs. $4 \mathrm{~h}, \mathrm{i})$. Consistent with the former two subperiods, during 2005-2019, the pattern of regressed GPI on the EMI is similar to that of GPI anomalies for El Niño Modoki $(r=0.58 ; p<0.01)$ and is almost the mirror image of GPI anomalies for La Niña Modoki $(r=-0.87 ; p<0.01)$.

As noted in previous studies (Kim et al. 2011; Patricola et al. 2018; Liu and Chen 2018; Choi et al. 2019), there is broad consistency between the regressions of GPIs and TC formation densities on ENSO indices. This implies that ENSO influences WNP TC formation through modulation of the large-scale environment, as the GPI consists of several environmental factors. In addition, given similarity among the patterns of regressed GPI on the EMI and GPI anomalies in different ENSO Modoki years during the three subperiods (Fig. 4), the influences of El Niño Modoki and La Niña Modoki on TC-related large-scale environments can both be captured by its regression on the EMI. Thus, we focus on the regressions on the EMI in the results that follow.

To further investigate how ENSO Modoki modulates large-scale environmental conditions responsible for WNP TC formation, the four parameters constituting the GPI, including MPI, RH600, VOR850, and SHR, are regressed on the EMI during the summer for the three subperiods (Figs. 5-8). Note that VOR850 is applied instead of absolute vorticity in the GPI equation since planetary vorticity does not change with time. In 1975-1989, there are only significant increases in MPI and RH600 near the dateline during El Niño Modoki (Figs. 5a, 6a). There are almost no significant changes in the four environmental factors over the TC main development region (Figs. 5a, 6a, 7a, 8a), likely explaining the lack of relationship between TC forma- 
Maximum Potential Intensity a) $1975-1989$

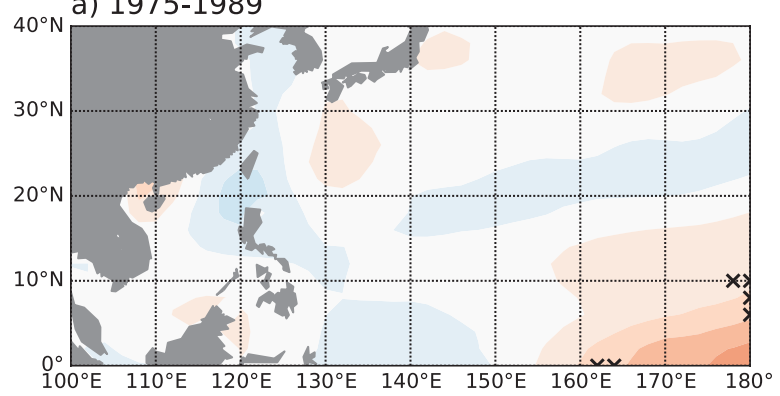

b) $1990-2004$

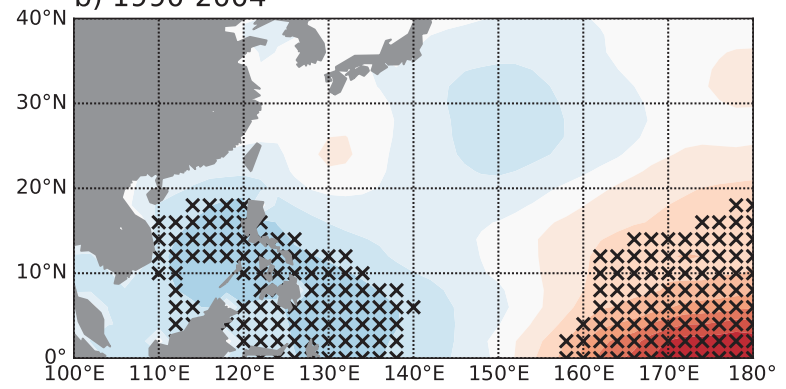

C) $2005-2019$

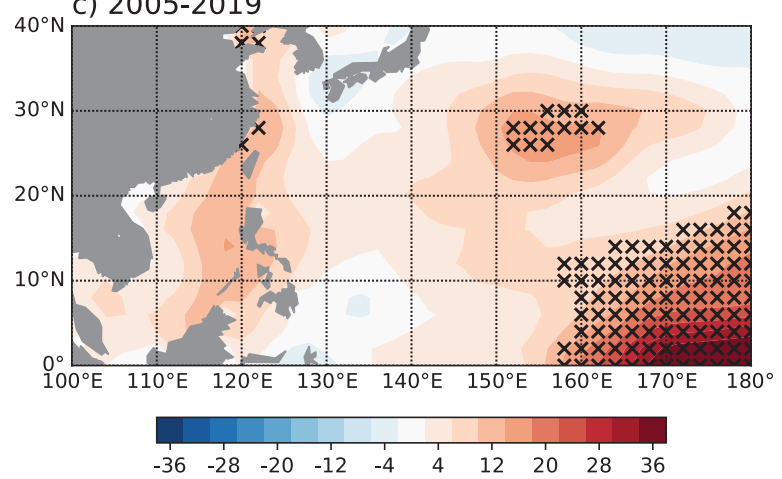

Fig. 5. Regression of maximum potential intensity (knots) on the EMI during the boreal summers of (a) 1975-1989, (b) 1990-2004 and (c) 20052019. Black crosses denote regressions significant at the 0.05 level based on an $F$-test.

tion and the EMI during 1975-1989 shown in Fig. 3a.

Compared with 1975-1989, the response of environmental variables to ENSO Modoki becomes more significant in 1990-2004 (Figs. 5b, 6b, 7b, 8b), as also reported by Liu and Chen (2018). The region with significantly enhanced TC formation during El Niño Modoki (the region bounded by $0-20^{\circ} \mathrm{N}$ and $130-$ $165^{\circ} \mathrm{E}$, as shown in Fig. $3 \mathrm{~b}$ ) has significantly increased RH600 and VOR850 (Figs. 6b, 7b). The region with significantly greater RH600 is primarily south of $10^{\circ} \mathrm{N}$ (Fig. 6b), while significantly larger VOR850 is
600-hPa Relative Humidity

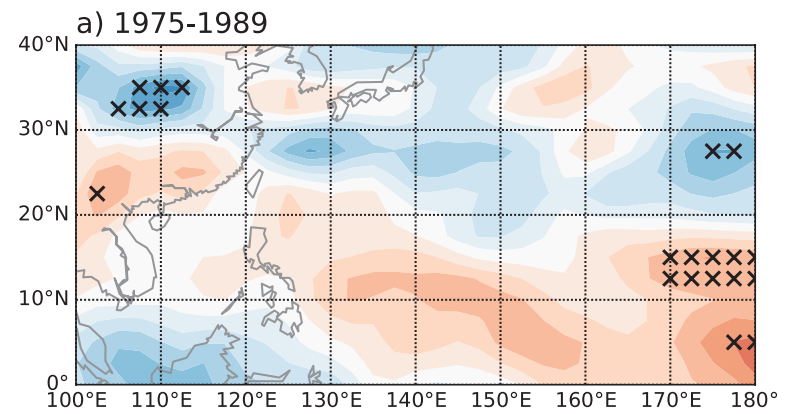

b) $1990-2004$

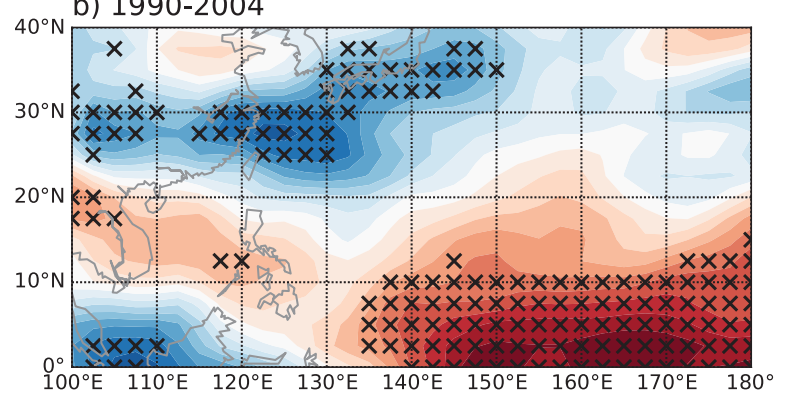

C) $2005-2019$

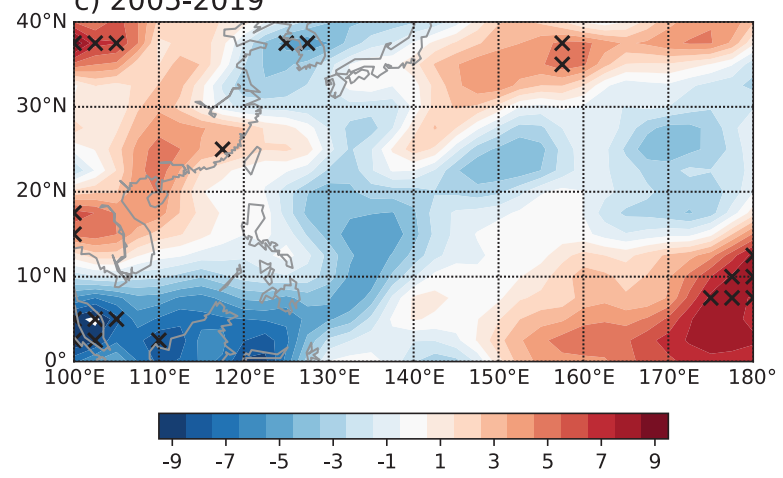

Fig. 6. As in Fig. 5, but for $600-\mathrm{hPa}$ relative humidity (\%).

concentrated within the latitudinal belt of $10-20^{\circ} \mathrm{N}$ (Fig. 7b). These results imply that ENSO Modoki's modulation of RH600 enhances TC formation in the southern part of the significant region, while ENSO Modoki's modulation of VOR850 has a greater impact in the northern part of the significant region. Although some publications have indicated a greater importance of local dynamic variables than local thermodynamic variables for WNP TC formation (Chan 2000; Wang and Chan 2002), both variables appear to contribute approximately equally to ENSO Modoki's modulation of TC formation. By comparison, significantly lower and greater MPIs occur only near the western and 


\section{0-hPa Relative Vorticity}

a) $1975-1989$

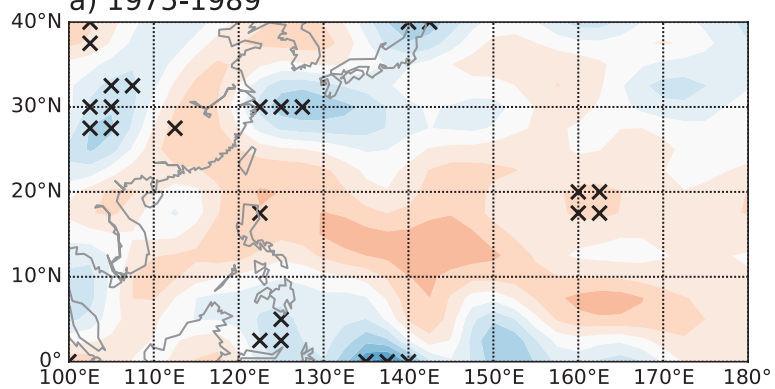

b) $1990-2004$

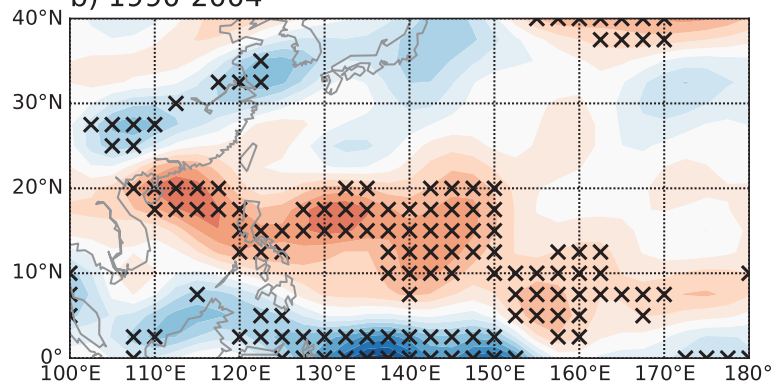

C) $2005-2019$

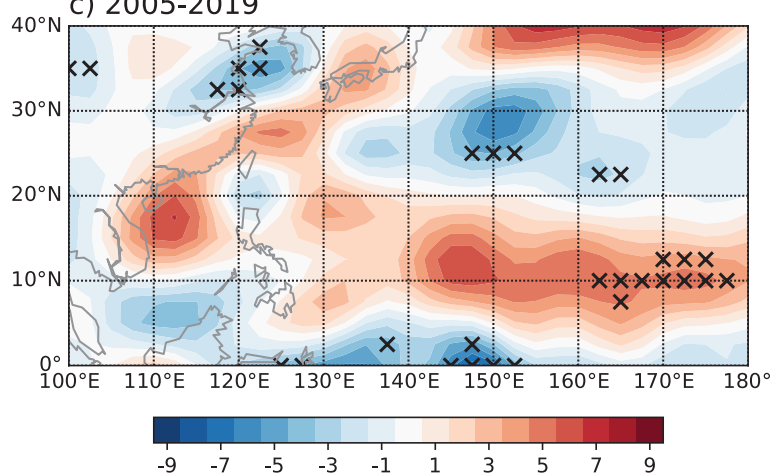

Fig. 7. As in Fig. 5, but for 850 -hPa relative vorticity $\left(\times 10^{-6} \mathrm{~s}^{-1}\right)$.

eastern boundary of the significant region, respectively (Fig. 5b), implying less of an influence of MPI on TC formation compared with RH600 and VOR850. Additionally, SHR changes over the WNP are mostly insignificant (Fig. 8b), implying that ENSO Modoki's influence on SHR had relatively little influence on WNP TC formation during 1990-2004. This result is somewhat different from the negative contribution of SHR shown in Choi et al. (2019), possibly due to the different analysis periods.

Figures $5 \mathrm{c}, 6 \mathrm{c}, 7 \mathrm{c}$, and $8 \mathrm{c}$ show four environmental factors regressed on the EMI during 2005-2019, which are similar to those during 1975-1989 (Figs.
850-200-hPa Vertical Wind Shear

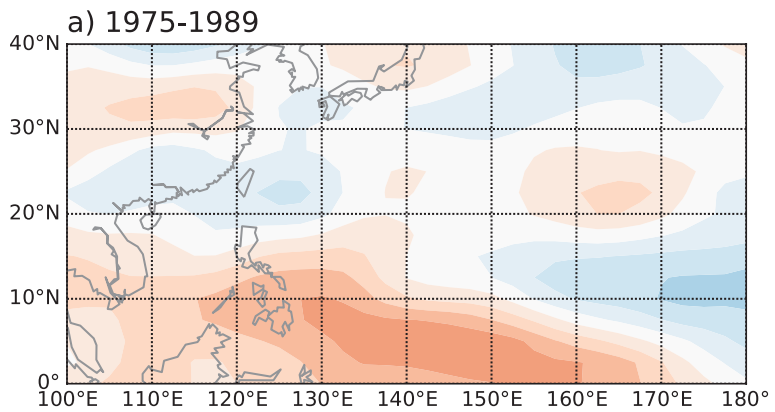

b) $1990-2004$

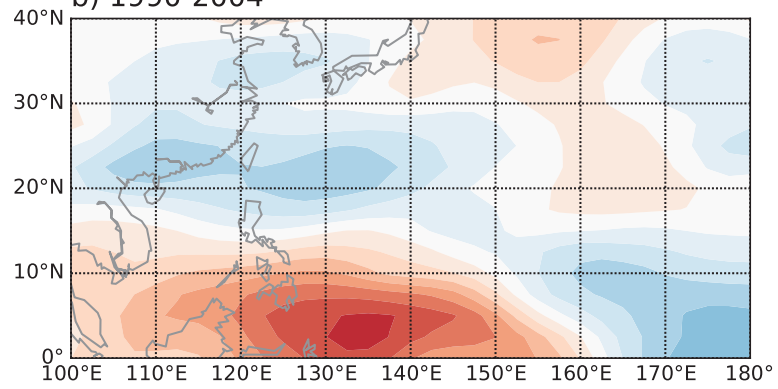

C) $2005-2019$

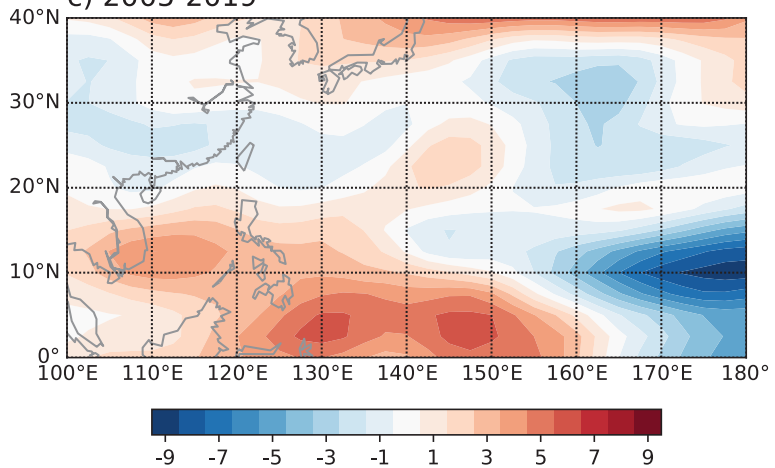

Fig. 8. As in Fig. 5, but for 850-200-hPa vertical wind shear $\left(\mathrm{m} \mathrm{s}^{-1}\right)$.

5a, 6a, 7a, 8a) but are of a larger magnitude. During El Niño Modoki, there is significantly larger MPI east of $160^{\circ} \mathrm{E}$ (Fig. $5 \mathrm{c}$ ), which significantly enhances GPI (Fig. 4g). Although there are also larger RH600 and VOR850 during El Niño Modoki, significant changes in these variables are only observed over a small area (Figs. 6c, 7c). However, the changes in TC formation density are not significant over this region (Fig. 3c), likely caused by the relatively low number of TCs that form in this area. By contrast, there are almost no significant changes in MPI, RH600 and VOR850 south of $20^{\circ} \mathrm{N}$ and west of $160^{\circ} \mathrm{E}$ (Figs. 5c, 6c, 7c), and there are no significant variations in SHR found 
a) $1975-1989$

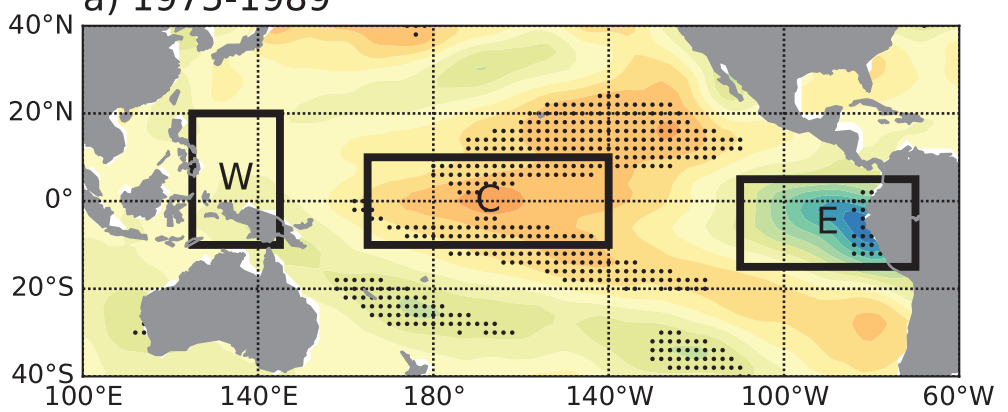

b) 1990-2004

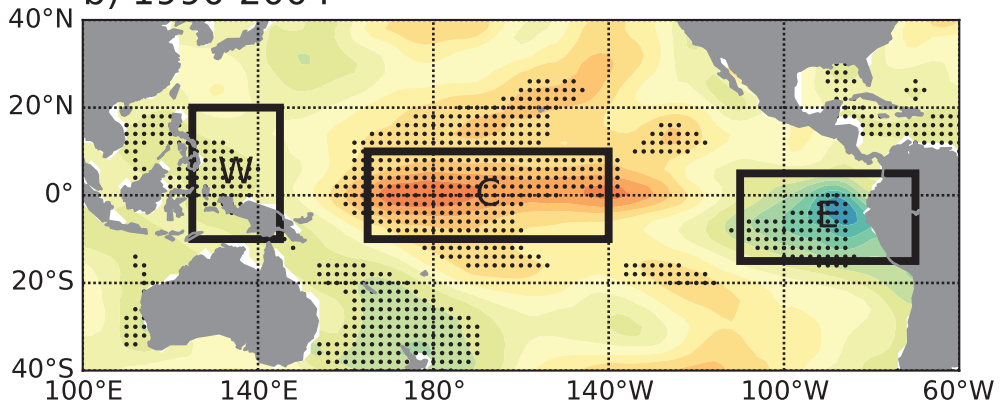

c) $2005-2019$

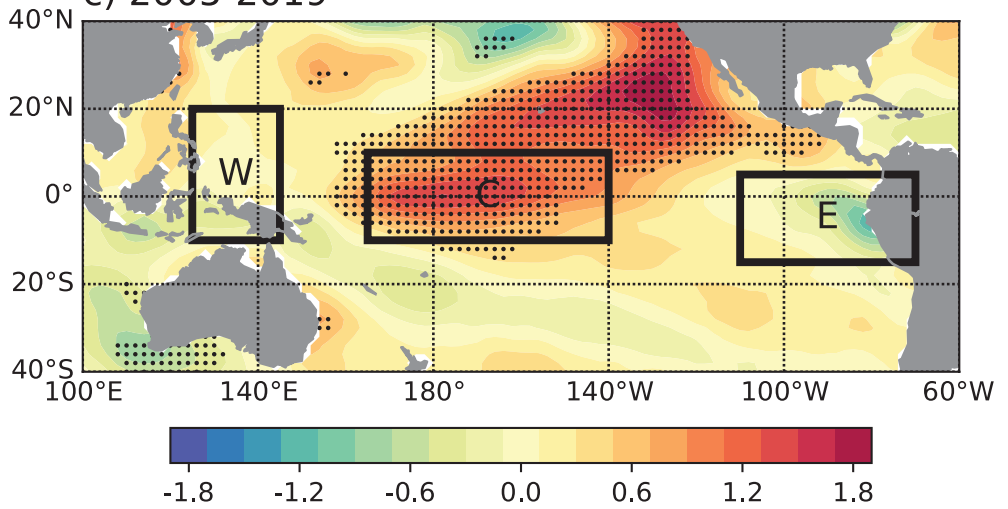

Fig. 9. Regression of SSTA $\left({ }^{\circ} \mathrm{C}\right)$ on the EMI during the boreal summer from (a) 1975-1989, (b) 1990-2004 and (c) 2005-2019. Regressions significant at the 0.05 level based on an $F$-test are stippled.

over the entire WNP (Fig. 8c). Consequently, there are only minor ENSO Modoki-modulated GPI changes over the WNP west of $160^{\circ} \mathrm{E}$ during 2005-2019 (Fig. $4 \mathrm{~g}$ ), likely leading to the observed small TC formation density variations (Fig. 3c). These results highlight that the modulation of several large-scale environmental variables by ENSO Modoki has become weaker in 1990-2004 and 2005-2019, likely explaining the aforementioned weakening relationship between ENSO Modoki and WNP TC formation.

\section{Possible mechanisms}

Figure 9 displays SST regressed on the EMI during JJA for 1975-1989, 1990-2004, and 2005-2019, highlighting the different ENSO Modoki SST patterns among the three subperiods. During the El Niño Modoki of 1975-1989, although positive SSTAs have a larger magnitude over the tropical central Pacific, they have greater significance over the subtropical northeastern Pacific (Fig. 9a). Significant negative SSTAs are observed only over the extreme eastern part of the tropical Pacific, while there are no significant 
SSTAs found over the western Pacific. This pattern is similar to the distribution of regressed SST onto the EMI during 1950-1990 (Liu and Chen 2018). In 1990-2004, significantly positive SSTAs during El Niño Modoki are concentrated over the tropical central Pacific, with maximum positive SSTAs near the equator and significantly lower SSTAs over the eastern and western Pacific (Fig. 9b). Note that this tripolar SST feature is similar to the typical ENSO Modoki SST pattern, as first proposed by Ashok et al. (2007). Comparatively, in 2005-2019, the SSTA regression on the EMI in the central tropical Pacific is of a greater magnitude than during the earlier two subperiods (Fig. 9c). The region with significantly greater SSTAs during El Niño Modoki extends from the equatorial tropical Pacific to the subtropical northeastern Pacific, with maximum positive SSTAs over the subtropical northeastern Pacific. The SSTA pattern is asymmetric between the two hemispheres, with most of the significant SSTAs occurring over the Northern Hemisphere. There are slightly positive SSTAs over the western Pacific, which opposes the typical ENSO Modoki pattern observed by Ashok et al. (2007). Although negative SSTAs still occur over the eastern Pacific, they are not significant and cover a relatively small area in 2005-2019 when compared with 1990-2004.

The tripolar SST pattern in the typical ENSO Modoki pattern is more obvious in 1990-2004 than in 1975-1989 and 2005-2019, with more significant eastern and western centers as well as the most significant SSTA concentrated over the equatorial central Pacific. These findings highlight that the EMI-regressed SSTA patterns in 1975-1989 and 2005-2019 are not solely modulated by the typical ENSO Modoki as shown in Ashok et al. (2007) but are also related to other climate modes. In addition, the most significantly positive SSTAs shift from the subtropical northeastern Pacific in 1975-1989 to the equatorial tropical Pacific in 1990-2004 and then shift back to the subtropical northeastern Pacific in 2005-2019.

Stuecker (2018) found that ENSO Modoki was significantly correlated with the simultaneous PMM phase, with the positive (negative) PMM often corresponding to El Niño Modoki (La Niña Modoki). The PMM exhibits a dipole SSTA pattern, with a positive phase being characterized by positive SSTAs over the subtropical northeastern Pacific and negative SSTAs over the tropical eastern Pacific. Figure 10 displays running correlations between the PMM and ENSO Modoki during JJA in a 15 -year sliding window. Although the relationship between the PMM index and the EMI has remained significant on a decadal

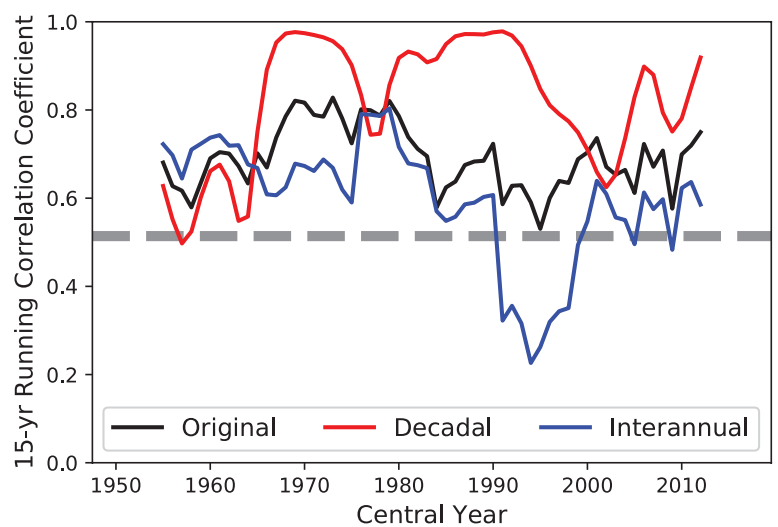

Fig. 10. 15-yr running correlation coefficient between the PMM index and the EMI during JJA of 1948-2019. The black line refers to the results from the original time series, while the red and blue lines denote the running correlations for decadal and interannual components, respectively. The decadal and interannual components of the time series are separated using an 11-point Gaussian filter. The horizontal dashed line represents the 0.05 significance level based on a Student's $t$-test.

timescale since the 1950s, the correlation strength has changed on interannual timescales. During the first and third subperiods (1975-1989 and 2005-2019), the strong interannual ENSO Modoki-PMM correlation is evidenced as positive SSTAs extending from the equatorial tropical Pacific to the subtropical northeastern Pacific during El Niño Modoki (Figs. 9a, c). By contrast, a weak interannual ENSO Modoki-PMM relationship is observed in 1990-2004, with greater SSTAs only concentrated over the equatorial tropical Pacific during El Niño Modoki (Fig. 9b). The difference in the SSTA pattern among the different subperiods (Fig. 9) is likely caused by interannual changes in the coupling between the PMM and ENSO Modoki (Fig. 10). Liu et al. (2019) reported that the statistically significant relationship between the PMM and WNP TC frequency was dominated by their linkage on decadal timescales. In contrast, WNP TC frequency was not significantly correlated with the PMM index on interannual timescales (Liu et al. 2019). It is likely that when the coupling between the PMM and ENSO Modoki strengthens (e.g., 1975-1989 and 2005-2019), the ENSO Modoki-TC frequency connection weakens due to the insignificant relationship between the PMM and TC frequency.

ENSO Modoki can induce a two-cell pattern in the 

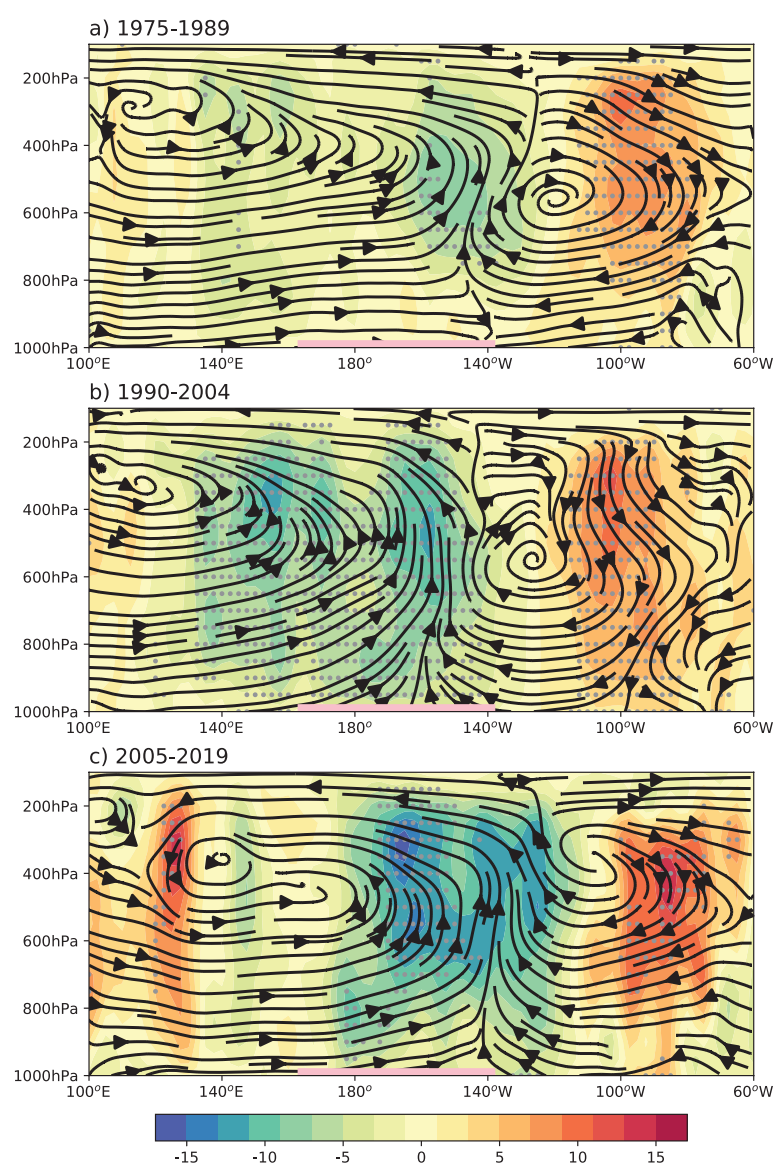

Fig. 11. Regressions of vertical velocity $\left(\mathrm{Pa} \mathrm{s}^{-1}\right.$; shaded) and vertical circulation (streamlines) averaged between the equator and $10^{\circ} \mathrm{N}$ on the EMI during the boreal summer for (a) 1975-1989, (b) 1990-2004 and (c) 2005-2019. Vertical velocity regressions at each pressure level are multiplied by 500 , while values significant at the 0.05 level based on an $F$-test are stippled. The pink solid line plotted at the bottom of each figure panel denotes Region $\mathrm{C}\left(165^{\circ} \mathrm{E}-140^{\circ} \mathrm{W}\right)$.

anomalous Walker circulation, with ascending motion over the central Pacific and descending motion over the eastern and western Pacific (Kim et al. 2011). However, there are also differences in the ENSO Modoki-modulated location and strength of the anomalous Walker circulation among the three subperiods (Figs. 11, 12). During 1990-2004, there is significant anomalous ascending motion between $140^{\circ} \mathrm{E}$ and $140^{\circ} \mathrm{W}$ during El Niño Modoki, with two main anomalous descending branches concentrated around $100^{\circ} \mathrm{E}$ and $100^{\circ} \mathrm{W}$ (Fig. 11b). The descending branch over the eastern Pacific is much stronger than that over the
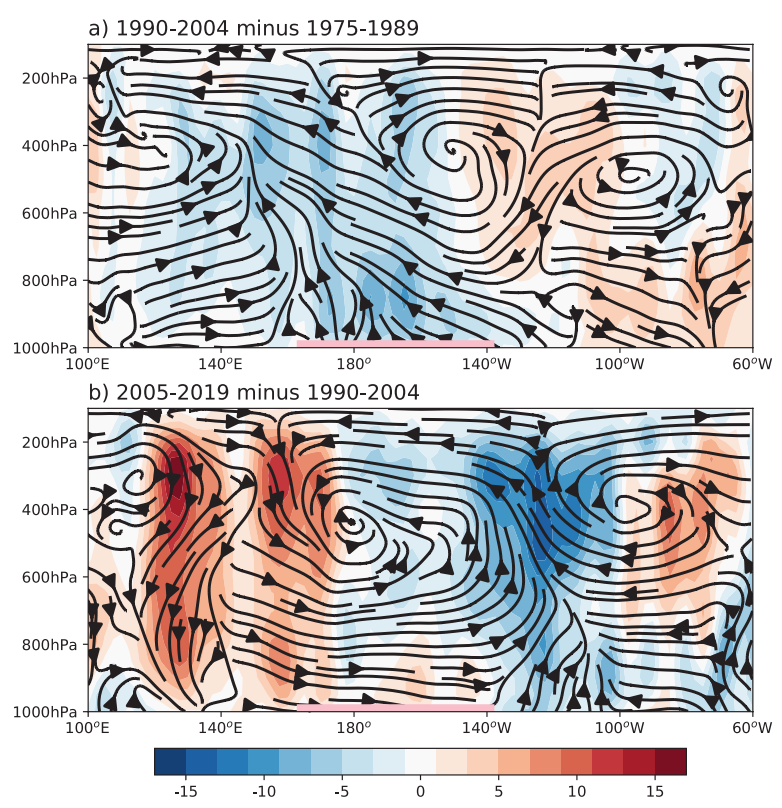

Fig. 12. As in Fig. 11, but for (a) the difference between 1975-1989 and 1990-2004 and (b) the difference between 1990-2004 and 2005-2019.

western Pacific. By comparison, although the anomalous Walker circulation is of a greater magnitude in 2005-2019 than in 1975-1989, it has similar patterns during these two subperiods (Figs. 11a, c). Although there are only slight changes in the descending branch over the eastern Pacific, anomalous ascending motion migrates eastward during El Niño Modoki, with significant ascending anomalies only occurring east of the dateline. In 1975-1989, there are almost no significant vertical motion responses to ENSO Modoki east of the dateline (Fig. 11a), possibly because of the lack of significant SSTAs over the western Pacific and the equatorial tropical Pacific (Fig. 9a). From 19751989 to 1990-2004, more anomalous upward motion induced by El Niño Modoki is observed east of dateline (Fig. 12a). These TC-favorable changes confirm the intensified modulation of WNP TC formation by ENSO Modoki since the early 1990s, as reported in Liu and Chen (2018). By comparison, in 2005-2019, the western descending branch strengthens and shifts eastward to $\sim 130^{\circ} \mathrm{E}$ during El Niño Modoki (Fig. $12 \mathrm{~b})$. This descending motion is linked to a meridional SST gradient between reduced positive SST anomalies over the western part of the WNP and increased positive SST anomalies over the equatorial tropical Pacific. The eastward migration of the western cell of the anomalous Walker circulation is also evident 
in Fig. 12b. Compared with 1990-2004, during El Niño Modoki of 2005-2019, there is enhanced ascending and descending motion over $140-100^{\circ} \mathrm{W}$ and $120^{\circ} \mathrm{E}-180^{\circ}$, respectively. The difference in the anomalous Walker circulation also exhibits an El Niño Modoki-like tripole pattern, which may imply that the strength of the summer ENSO Modoki has increased over the past three decades.

Figures 13a, b shows the 1975-2019 boreal summer mean $850-\mathrm{hPa}$ circulation and $500-\mathrm{hPa}$ vertical velocity. Climatologically, there is an ascending and descending motion over the western and eastern tropical Pacific, respectively, associated with lowlevel easterlies over the equatorial Pacific. Figures $13 \mathrm{c}, 13 \mathrm{e}$, and $13 \mathrm{~g}$ displays the low-level horizontal circulation regressed on the EMI for the three subperiods. During El Niño Modoki events in 1975-1989 and 2005-2019, consistent with an eastward migration of the western cell of the anomalous Walker circulation (Figs. 11a, c), anomalous low-level westerlies shift eastward (Figs. 13c, g). The stronger 850$\mathrm{hPa}$ westerlies are concentrated over the eastern part of the WNP (Figs. 13c, g), inducing larger VOR850s near the dateline due to the shear effect (Figs. 7a, c). Furthermore, most of the tropical WNP is governed by a large-scale deformation field, which is formed by an anomalous anticyclonic circulation centered near $25^{\circ} \mathrm{N}, 150^{\circ} \mathrm{E}$ (Figs. $13 \mathrm{c}, \mathrm{g}$ ). This anomalous anticyclonic circulation causes only slight changes in the relative vorticity field (Figs. 7a, c). By contrast, during 1990-2004, significantly greater low-level westerlies are found over the equatorial region bounded by 120 $160^{\circ} \mathrm{E}$, with an anomalous cyclonic circulation over the WNP centered at $\sim 20^{\circ} \mathrm{N}, 150^{\circ} \mathrm{E}$ (Fig. 13e). These features lead to larger VOR850s over almost the entire WNP during this period (Fig. 7b) through both the shear effect and the anomalous cyclone itself.

The changes in mid-level moisture over the WNP can largely be explained by changes in vertical motion since greater upward motion carries more moisture from the underlying sea to the atmosphere. In 19751989, significant upward motion is concentrated over the subtropical northeastern Pacific, while most of the WNP has little significant change in vertical motion (Fig. 13d). This is likely caused by relatively smaller SSTA changes related to ENSO Modoki during this period (Fig. 9a). In 1990-2004, anomalous ascending motion from $0^{\circ}$ to $10^{\circ} \mathrm{N}$ enhances upward transport of moisture from the underlying ocean (Fig. 13f). In the tropical Pacific east of $130^{\circ} \mathrm{E}$, a moister midtroposphere (Fig. 6b) favors TC formation. The EMI can explain nearly half of the variance in vertical motion over the tropical WNP (figures not shown). By contrast, during El Niño Modoki in 2005-2019, the mid-level vertical velocity field shows almost no significant ENSO Modoki-modulated changes over the WNP (Fig. 13h), consistent with small anomalies in vertical motion between $130^{\circ} \mathrm{E}$ and $180^{\circ}$ in Fig. $11 \mathrm{c}$. There is consequently a lack of sufficient anomalous upward moisture transport during El Niño Modoki to cause significant changes in the mid-level relative humidity field (Fig. 6c). These results show that different ENSO Modoki patterns can result in different horizontal and vertical circulation patterns that further lead to different changes in large-scale environmental variables.

\section{Conclusions}

This study investigates decadal changes in the interannual relationship between ENSO Modoki and WNP TC formation during the summer from 1945 to 2019. WNP TC frequency is significantly correlated with the EMI on decadal timescales, while it is weakly linked to the EMI on interannual timescales. We also find decadal changes in the observed TC frequencyEMI relationship when the period with more reliable TC data (1975-2019) is considered. The correlation between the EMI and TC frequency over the WNP is weak between 1975 and 1989, becomes strong and significant during 1990-2004, and becomes weak again during 2005-2019. This indicates a weakening of the ENSO Modoki-WNP TC frequency relationship since the mid-2000s. Moreover, there are differences in ENSO Modoki-modulated TC formation locations during the three subperiods. During El Niño Modoki, TC formation is enhanced over the eastern part of the WNP (east of $130^{\circ} \mathrm{E}$ ) from 1990 to 2004 , while TC formation density over the WNP shows little relationship with El Niño Modoki over the entire WNP for 1975-1989 and 2005-2019.

Although there are several environmental variables influencing TC formation, mid-level moisture (e.g., RH600) and low-level vorticity (e.g., VOR850) appear to be the two leading factors leading to the differential response in ENSO Modoki-caused changes in WNP TC formation during the three subperiods. From 1990 to 2004, the enhancement of TC formation during El Niño Modoki south and north of $20^{\circ} \mathrm{N}$ is primarily attributed to greater RH600 and larger VOR850, respectively. By comparison, there are almost no significant ENSO Modoki-driven changes in RH600 and VOR850 over the main TC formation region during 1975-1989 and 2005-2019 (south of $20^{\circ} \mathrm{N}$ and west of $160^{\circ} \mathrm{E}$ ). These findings also highlight that ENSO 

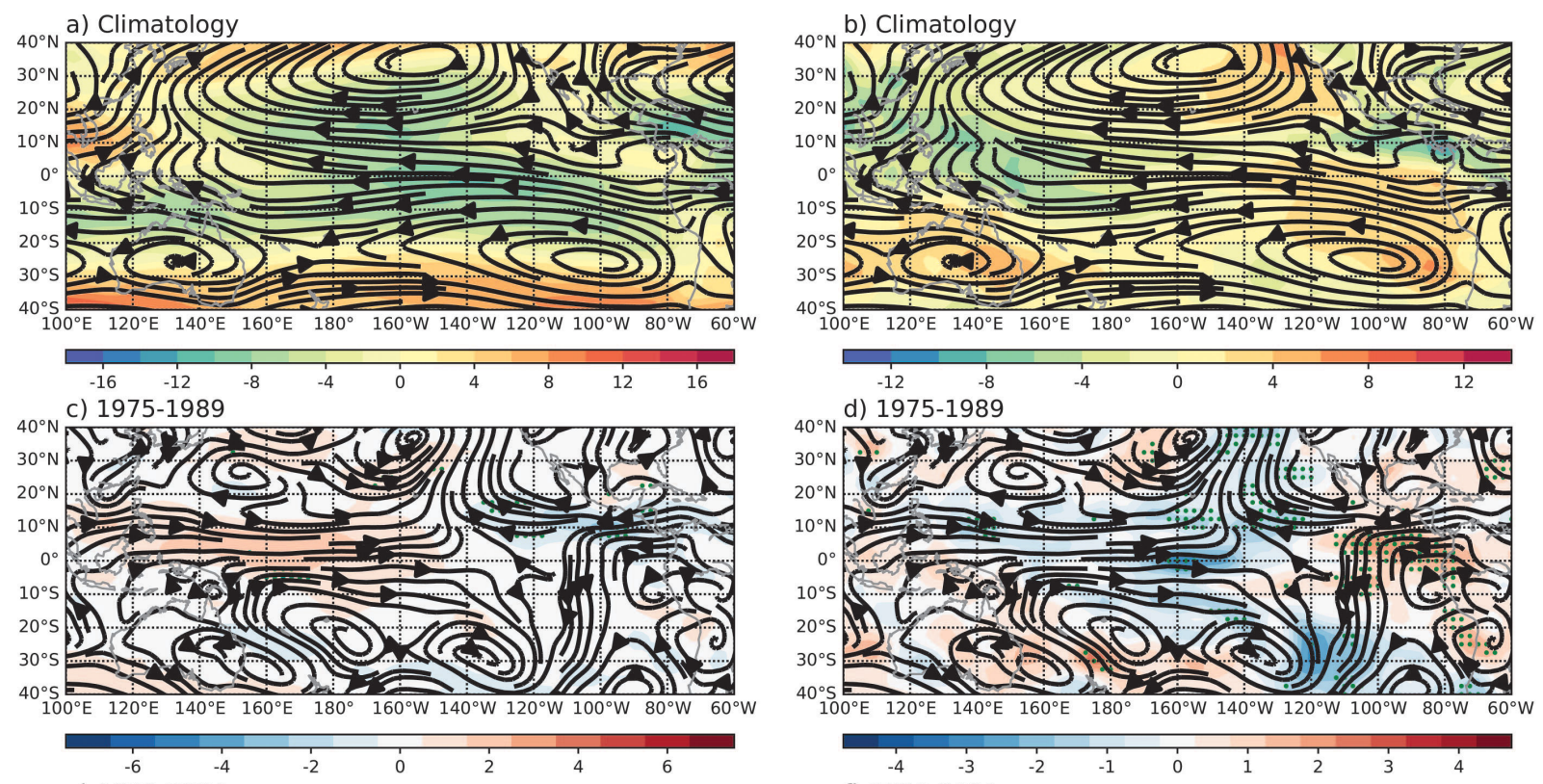

e) $1990-2004$
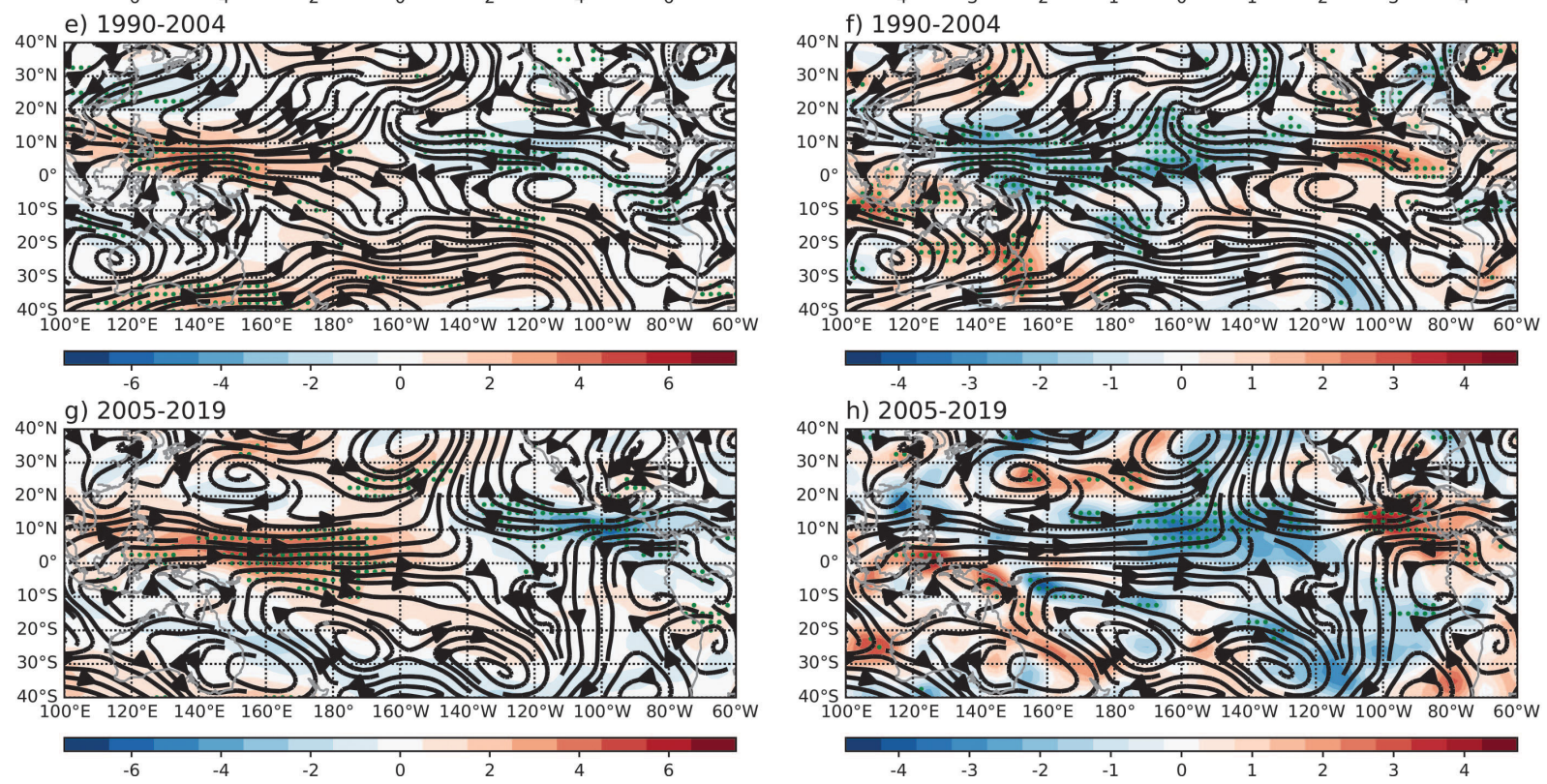

Fig. 13. (a, b) JJA means of 850-hPa wind (streamlines), as well as (a) 850-hPa zonal wind ( $\mathrm{m} \mathrm{s}^{-1}$; shaded) and (b) 500-hPa vertical velocity $\left(\times 10^{-2} \mathrm{~Pa} \mathrm{~s}^{-1}\right.$; shaded) during 1975-2019. (c-h) Regressions of 850-hPa wind (streamlines), as well as (c, e, g) 850-hPa zonal wind ( $\mathrm{m} \mathrm{s}^{-1}$; shaded) and (d, f, h) 500-hPa vertical velocity $\left(\times 10^{-2} \mathrm{~Pa} \mathrm{~s}^{-1}\right.$; shaded) on the EMI during the boreal summer for (b) 1975-1989, (c) 1990-2004 and (d) 2005-2019. Zonal wind speeds and vertical velocities significant at the 0.05 level based on an $F$-test are shown as green circles.

Modoki appears to have little impact on RH600 and VOR850 during 2005-2019, likely leading to the lack of relationship noted in recent years.

The different ENSO Modoki-WNP TC formation relationships noted among 1975-1989, 1990-2004, and 2005-2019 are further linked to different spatial SST patterns of ENSO Modoki events during these three subperiods. More specifically, El Niño Modoki in 1990-2004 exhibited a tripolar SSTA pattern, with a maximum positive SSTA centered over the equato- 
rial central Pacific. In 1975-1989 and 2005-2019, the region with significantly positive SSTAs during El Niño Modoki extended from the equatorial tropical Pacific to the subtropical northeastern Pacific, with the maximum in positive SSTAs occurring over the subtropical northeastern Pacific. Although there are differences in the EMI-regressed SSTA and other environmental variables between 1975-1989 and 20052019, the EMI-TC frequency relationships are weak and insignificant during both subperiods. We note that maximum positive SSTAs occur over the subtropical northeastern Pacific during both 1975-1989 and 2005-2019, but not over the equatorial central Pacific as they do during 1990-2004. This means that the strength of the connection between ENSO Modoki and WNP TC frequency is sensitive to the location of the maximum positive SSTAs. Additionally, there are no significant ENSO Modoki-modulated changes in SSTAs over the eastern Pacific. During El Niño Modoki, the migration of SSTAs can cause substantial changes in both the vertical and the horizontal atmospheric circulation. From 1975-1989 to 1990-2004, there is a strengthened eastern cell of the anomalous Walker circulation induced by El Niño Modoki, which represents a basinwide enhancement of upward motion over the WNP. This change favors TC formation, resulting in the intensified TC frequency-EMI relationship during 1990-2004. By comparison, from 19902004 to 2005-2019, there has been an eastward shift of the anomalous Walker circulation driven by El Niño Modoki, inducing a noticeable weakening of anomalous ascending motion over the eastern part of the WNP. This weakened anomalous ascending motion causes a decrease in the mid-level moisture transported from the underlying sea surface. Meanwhile, during El Niño Modoki, the anomalous cyclonic circulation over the tropical WNP in 1990-2004 is replaced by an anomalous deformation field in 2005-2019, leading to a reduction in mid-level cyclonic vorticity.

Zhao and Wang (2019) reported a strengthened relationship between WNP TC frequency and a traditional ENSO index (Niño-3.4 SSTA) since the late 1990s, which was attributed to the shift of the dominant ENSO mode from canonical ENSO to ENSO Modoki. Zhao and Wang (2019) also linked the reduction in basinwide TC frequency since the late 1990s to the PDO phase change from positive to negative, which was further explained by more frequent La Niña Modoki occurrences during a negative PDO phase than during a positive PDO phase (Kim et al. 2020). Both studies implied a strong WNP TC-ENSO Modoki relationship since the negative PDO phase began in the late 1990s. By comparison, during this negative PDO phase, our results show an unstable WNP TC-ENSO Modoki relationship on interannual timescales. The WNP TC-ENSO Modoki correlation changed from strong to weak in the mid-2000s, while the PDO phase switch occurred several years earlier and has remained generally negative since that time.

As found in Yeh et al. (2009), the proportion of ENSO Modoki events to canonical ENSO events is projected to increase under a global warming scenario. Considering that ENSO Modoki has shown different relationships with WNP TC formation during the past 45 years, we suggest investigating how the ENSO Modoki SSTA pattern may change under global warming and focusing on the coupling between ENSO Modoki and the PMM. These changes may be crucial in determining how to apply ENSO Modoki-related indices for statistical or statistical-dynamical model prediction of JJA TC frequency over the WNP.

\section{Acknowledgments}

This work was jointly funded by the National Key Research and Development Program of China (2018 YFC1507305), the National Natural Science Foundation of China (61827901) and the China Postdoctoral Science Foundation (2020M680789). Klotzbach would like to acknowledge financial support from the $\mathrm{G}$. Unger Vetlesen Foundation.

\section{References}

Ashok, K., S. K. Behera, S. A. Rao, H. Weng, and T. Yamagata, 2007: El Niño Modoki and its possible teleconnection. J. Geophys. Res., 112, C11007, doi:10.1029/ 2006JC003798.

Camargo, S. J., K. A. Emanuel, and A. H. Sobel, 2007: Use of a genesis potential index to diagnose ENSO effects on tropical cyclone genesis. J. Climate, 20, 48194834.

Capotondi, A., A. T. Wittenberg, M. Newman, E. Di Lorenzo, J.-Y. Yu, P. Braconnot, J. Cole, B. Dewitte, B. Giese, E. Guilyardi, F.-F. Jin, K. Karnauskas, B. Kirtman, T. Lee, N. Schneider, Y. Xue, and S.-W. Yeh, 2015: Understanding ENSO diversity. Bull. Amer. Meteor. Soc., 96, 921-938.

Chan, J. C. L., 1985: Tropical cyclone activity in the northwest Pacific in relation to the El Niño/Southern Oscillation phenomenon. Mon. Wea. Rev., 113, 599-606.

Chan, J. C. L., 2000: Tropical cyclone activity over the western North Pacific associated with El Niño and La Niña events. J. Climate, 13, 2960-2972.

Chan, J. C. L., 2005: Interannual and interdecadal variations of tropical cyclone activity over the western North Pacific. Meteor. Atmos. Phys., 89, 143-152. 
Chen, G., and C.-Y. Tam, 2010: Different impacts of two kinds of Pacific Ocean warming on tropical cyclone frequency over the western North Pacific. Geophys. Res. Lett., 37, L01803, doi:10.1029/2009GL041708.

Choi, K.-S., H.-D. Kim, S.-D. Kang, and C.-S. Shim, 2016: Decreasing trend of tropical cyclone genesis frequency in July-August over the western North Pacific in the last 20 years. Theor. Appl. Climatol., 125, 241251.

Choi, Y., K.-J. Ha, and F.-F. Jin, 2019: Seasonality and E1 Niño diversity in the relationship between ENSO and western North Pacific tropical cyclone activity. $J$. Climate, 32, 8021-8045.

Chu, J.-H., C. R. Sampson, A. S. Levine, and E. Fukada, 2002: The Joint Typhoon Warning Center tropical cyclone best-tracks, 1945-2000. NRL/MR/7540-02-16, Best Track Archive, Naval Oceanography Portal, Naval Meteorology and Oceanography Command. [Available at https://www.metoc.navy.mil/jtwc/products/besttracks/tc-bt-report.html.]

Cooper, G. A., and R. J. Falvey, 2009: Annual tropical cyclone report. U.S. Naval Maritime Forecast Center/ Joint Typhoon Warming Center, Naval Oceanography Portal, Naval Meteorology and Oceanography Command, 109 pp. [Available at https:/www.metoc.navy. mil/jtwc/products/atcr/2009atcr.pdf.]

Emanuel, K. A., 1988: The maximum intensity of hurricanes. J. Atmos. Sci., 45, 1143-1155.

Emanuel, K. A., 2018: 100 years of progress in tropical cyclone research. Meteor. Monogr., 59, 15.1-15.68.

Emanuel, K. A., and D. S. Nolan, 2004: Tropical cyclone activity and global climate system. Proceeding of 26th Conference on Hurricanes and Tropical Meteorology, Miami, FL, Amer. Meteor. Soc., 240-241.

Fudeyasu, H., K. Ito, and Y. Miyamoto, 2018: Characteristics of tropical cyclone rapid intensification over the western North Pacific. J. Climate, 31, 8917-8930.

Gershunov, A., N. Schneider, and T. Barnett, 2001: Lowfrequency modulation of the ENSO-Indian monsoon rainfall relationship: Signal or noise? J. Climate, 14, 2486-2492.

Hsu, P.-C., C.-R. Ho, S.-J. Liang, and N.-J. Kuo, 2013: Impacts of two types of El Niño and La Niña events on typhoon activity. Adv. Meteor, 2013, 632470, doi: 10.1155/2013/632470.

Huang, B., P. W. Thorne, V. F. Banzon, T. Boyer, G. Chepurin, J. H. Lawrimore, M. J. Menne, T. M. Smith, R. S. Vose, and H.-M. Zhang, 2017: Extended reconstructed sea surface temperature, version 5 (ERSSTv5): Upgrades, validations, and intercomparisons. J. Climate, 30, 8179-8205.

Huang, X., X. Peng, J. Fei, X. Cheng, J. Ding, and D. Yu, 2021: Evaluation and error analysis of official tropical cyclone intensity forecasts during 2005-2018 for the western North Pacific. J. Meteor. Soc. Japan, 99, 139-163.
Kalnay, E., M. Kanamitsu, R. Kistler, W. Collins, D. Deaven, L. Gandin, M. Iredell, S. Saha, G. White, J. Woollen, Y. Zhu, M. Chelliah, W. Ebisuzaki, W. Higgins, J. Janowiak, K. C. Mo, C. Ropelewski, J. Wang, A. Leetmaa, R. Reynolds, R. Jenne, and D. Joseph, 1996: The NCEP/NCAR 40-year reanalysis project. Bull. Amer. Meteor. Soc., 77, 437-472.

Kao, H.-Y., and J.-Y. Yu, 2009: Contrasting eastern-Pacific and central-Pacific types of ENSO. J. Climate, 22, 615-632.

Kim, H.-M., P. J. Webster, and J. A. Curry, 2011: Modulation of North Pacific tropical cyclone activity by three phases of ENSO. J. Climate, 24, 1839-1849.

Kim, H.-K., K.-H. Seo, S.-W. Yeh, N.-Y. Kang, and B.-K. Moon, 2020: Asymmetric impact of central Pacific ENSO on the reduction of tropical cyclone genesis frequency over the western North Pacific since the late 1990s. Climate Dyn., 54, 661-673.

Knapp, K. R., M. C. Kruk, D. H. Levinson, H. J. Diamond, and C. J. Neumann, 2010: The International Best Track Archive for Climate Stewardship (IBTrACS). Bull. Amer. Meteor. Soc., 91, 363-376.

Lander, M. A., 1994: An exploratory analysis of the relationship between tropical storm formation in the western North Pacific and ENSO. Mon. Wea. Rev., 122, 636651.

Lee, C.-S., K. K. W. Cheung, J. S. N. Hui, and R. L. Elsberry, 2008: Mesoscale features associated with tropical cyclone formations in the western North Pacific. Mon. Wea. Rev., 136, 2006-2022.

Li, R. C. Y., and W. Zhou, 2012: Changes in western Pacific tropical cyclones associated with the El Niño-Southern Oscillation cycle. J. Climate, 25, 5864-5878.

Liu, C., W. Zhang, M. F. Stuecker, and F.-F. Jin, 2019: Pacific Meridional Mode-western North Pacific tropical cyclone linkage explained by tropical Pacific quasidecadal variability. Geophys. Res. Lett., 46, 1334613354.

Liu, Y., and G. Chen, 2018: Intensified influence of the ENSO Modoki on boreal summer tropical cyclone genesis over the western North Pacific since the early 1990s. Int. J. Climatol., 38, e1258-e1265.

Ma, Z., J. Fei, Y. Lin, and X. Huang, 2020: Modulation of clouds and rainfall by tropical cyclone's cold wakes. Geophys. Res. Lett., 47, e2020GL088873, doi:10.1029/ 2020 GL088873.

O'hara, J. F., and R. Falvey, 2006: Annual tropical cyclone report. Lana, LT A. D. (ed.), U. S. Naval Maritime Forecast Center/Joint Typhoon Warming Center, Naval Oceanography Portal, Naval Meteorology and Oceanography Command, 98 pp. [Available at https://www. metoc.navy.mil/jtwc/products/atcr/2006atcr.pdf.]

Patricola, C. M., S. J. Camargo, P. J. Klotzbach, R. Saravanan, and P. Chang, 2018: The influence of ENSO flavors on western North Pacific tropical cyclone activity. J. Climate, 31, 5395-5416. 
Ritchie, E. A., and G. J. Holland, 1999: Large-scale patterns associated with tropical cyclogenesis in the western Pacific. Mon. Wea. Rev., 127, 2027-2043.

Saunders, M. A., R. E. Chandler, C. J. Merchant, and F. P. Roberts, 2000: Atlantic hurricanes and NW Pacific typhoons: ENSO spatial impacts on occurrence and landfall. Geophys. Res. Lett., 27, 1147-1150.

Stuecker, M. F., 2018: Revisiting the Pacific Meridional Mode. Sci. Rep., 8, 3216, doi:10.1038/s41598-01821537-0.

Timmermann, A., S.-I. An, J.-S. Kug, F.-F. Jin, W. Cai, A. Capotondi, K. M. Cobb, M. Lengaigne, M. J. McPhaden, M. F. Stuecker, K. Stein, A. T. Wittenberg, K.-S. Yun, T. Bayr, H.-C. Chen, Y. Chikamoto, B. Dewitte, D. Dommenget, P. Grothe, E. Guilyardi, Y.-G. Ham, M. Hayashi, S. Ineson, D. Kang, S. Kim, W. Kim, J.-Y. Lee, T. Li, J.-J. Luo, S. McGregor, Y. Planton, S. Power, H. Rashid, H.-L. Ren, A. Santoso, K. Takahashi, A. Todd, G. Wang, G. Wang, R. Xie, W.-H. Yang, S.-W. Yeh, J. Yoon, E. Zeller, and X. Zhang, 2018: El Niño-Southern Oscillation complexity. Nature, 559, 535-545.
Wang, B., and J. C. L. Chan, 2002: How strong ENSO events affect tropical storm activity over the western North Pacific. J. Climate, 15, 1643-1658.

Wang, C., C. Deser, J.-Y. Yu, P. DiNezio, and A. Clement, 2017: El Niño and Southern Oscillation (ENSO): A review. Coral Reefs of the Eastern Pacific. Glynn, P. W., D. P. Manzello, and I. C. Enochs (eds.), Springer, Netherlands, 85-106.

Yeh, S.-W., J.-S. Kug, B. Dewitte, M.-H. Kwon, B. P. Kirtman, and F.-F. Jin, 2009: El Niño in a changing climate. Nature, 461, 511-514.

Yoshida, R., and H. Ishikawa, 2013: Environmental factors contributing to tropical cyclone genesis over the western North Pacific. Mon. Wea. Rev., 141, 451-467.

Zhang, W., Y. Leung, and K. Fraedrich, 2015: Different El Niño types and intense typhoons in the western North Pacific. Climate Dyn., 44, 2965-2977.

Zhao, H., and C. Wang, 2019: On the relationship between ENSO and tropical cyclones in the western North Pacific during the boreal summer. Climate Dyn., 52, 275-288. 